\title{
Micro-seismic precursory cracks prior to rock-fall on coastal chalk cliffs: a case study at Mesnil-Val, Normandie, NW France
}

\author{
G. Senfaute ${ }^{1}$, A. Duperret ${ }^{2}$, and J. A. Lawrence ${ }^{3}$ \\ ${ }^{1}$ INERIS - Institut National de l'Environnement Industriel et des Risques, Parc technologique Alata BP 2, \\ 60550 Verneuil en Halatte, France \\ ${ }^{2}$ FRE3102 - CNRS Laboratoire Ondes et Milieux Complexes, Université du Havre, 53 rue de Prony, BP540, \\ 76053 Le Havre cedex, France \\ ${ }^{3}$ School of the Earth and Environment, University of Leeds, Leeds, Yorkshire, LS2 9JT, UK
}

Received: 12 March 2009 - Revised: 28 August 2009 - Accepted: 4 September 2009 - Published: 2 October 2009

\begin{abstract}
Erosion of rock cliffs has been considered to be relatively unpredictable. This perceived stochastic nature of the erosional processes often occurs through collapses along fractures in the rock-mass. The prediction of catastrophic cliff failures and collapses remains very difficult. For advancing in this field, it is important to understand the processes through which a crack is initiated, how it develops and propagates until the final failure. This paper examines the micro-seismic signals recorded $15 \mathrm{~h}$ prior to a rock-fall located at Mesnil-Val, France. The results lead to the hypothesis that several phases of failure mechanisms contribute to rock-fall occurrence. The most important phases were associated with micro-seismic event families identified by multiplet selection. Each event family contained one specific frequency spectrum showing a progressive decrease of the frequencies as the rock approached failure suggesting the following phases: 1) the micro-seismic events recorded $15 \mathrm{~h}$ before the rock-fall were characterised by the highest frequencies in a large spectrum-band, between $\sim 100$ and $1000 \mathrm{~Hz}$ (family 1), suggesting a crack initiation mechanism or the opening of existing fractures; 2) the micro-seismic events recorded several minutes before the rock-fall were associated with a clear decrease in the highest frequency components (family 2) suggesting that the mechanism was related to the growing and development (or coalesce) of existing micro-cracks into larger fractures; 3) micro-seismic events recorded just before the rock-fall were associated with
\end{abstract}

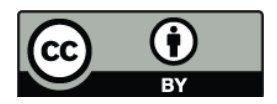

Correspondence to: G. Senfaute (gloria.senfaute@ineris.fr) a lower frequency spectrum than families 1 and 2, the highest frequency components were absent (family 3), the frequency emission source mechanism could be related to the shearing or opening of the existing large fractures permitting the complete detachment of the blocky rock-mass; 4) finally, micro-seismic events with a very low frequency spectrum (lower than $100 \mathrm{~Hz}$ ) characterized the rock-fall impact on the ground. These encouraging results offer the possibility of using the micro-seismic system to monitor high risk sections of coastline and to advance understanding of cliff failure mechanisms.

\section{Introduction}

A large proportion of European coastlines are subjected to erosion and cliff recession. On coastal chalk cliffs, this is producing catastrophic collapses (e.g. Mortimore et al., 2004; Duperret et al., 2004), which raise problems of security, land-use planning and management of coastal areas. Investigations along $120 \mathrm{~km}$ chalk coastline in Normandie and Picardie, France identified 55 significant collapses with volumes ranging from about $100 \mathrm{~m}^{3}$ to $85000 \mathrm{~m}^{3}$ and the larger collapses were capable of taking a bite out of the cliff face between 10-20 $\mathrm{m}$ deep during a single event (Duperret et al., 2002, 2004). These apparent instantaneous collapses contribute to long-term mean erosion rates estimated to be $0.23 \mathrm{~m} /$ year during the last 30 years, along Normandie and Picardie coastline (Costa, 2000; Costa et al., 2004). The same process occurs on coastal chalk cliffs of Sussex and Kent in the UK (Mortimore et al., 2004), where long-term

Published by Copernicus Publications on behalf of the European Geosciences Union. 


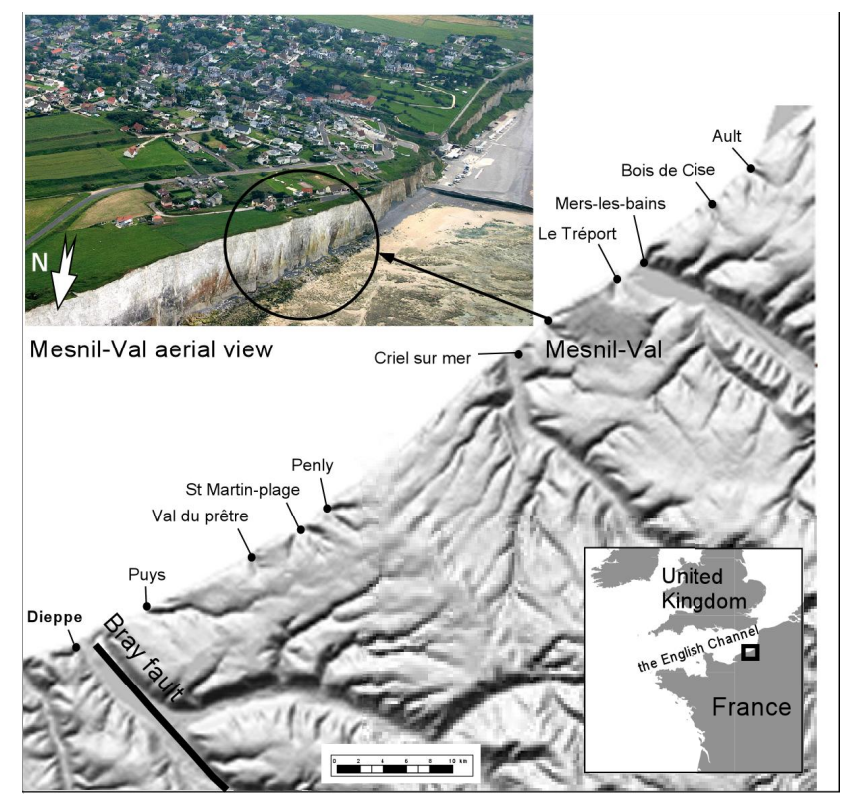

Fig. 1. Location of the study area, Haute-Normandie, France. DEM is $50 \mathrm{~m}$ resolution and topographic data are treated using Synergis software from BRGM. The aerial photograph was taken by Dubois the 13 June 2007 (www.survoldefrance.fr).

coastal recession is estimated to be $0.35 \mathrm{~m} / \mathrm{year}$ for the last 100 years (Dornbusch et al., 2006). Unfortunately, understanding the actual mechanisms of coastal cliff retreat is poorly developed. Some elements are well-established, for example the role of the pre-existing fractures in the generation of block failure from the cliff (Hoek and Bray, 1981; Priest, 1993; Duperret et al., 2004; Busby and Jackson, 2006; Freyssines and Hantz, 2006). However, whilst the fractures clearly provide weaknesses along which many failures develop, the triggering processes including fracture development leading to failure remains poorly understood because it is associated with the difficulty of long-term monitoring and data collection.

The standard tools commonly implemented to detect movement of blocks expected to fall and to help understand the failure process are displacement transducers, GPS stations and inclinometers (Jaboyedoff et al., 2004; Gunzburger et al., 2005) or precise laser scanning of the cliff face to detect block movements and superficial geomorphological changes (Mikos et al., 2005; Dewez et al., 2007; Collins and Sitar, 2008). Some geophysical methods have been developed to image small-scale fracture networks along vertical cliffs to detect the precise 3-D characteristics of the fracture network along which failure planes develop, these are electrical methods, such as azimuthal apparent resistivity (Busby and Jackson, 2006) and ground penetrating radar (GPR) using electromagnetic waves (Jeannin et al., 2006; Roch et al., 2006; Deparis et al., 2007), but their application in determining cliff failure at depth and over wide areas is very limited. Some large-scale cliff collapses have been detected using seismic monitoring. Large-scale landslides were recorded by seismic observatories at local and tele-seismic distances during the Mantaro landslide $\left(1.3 \mathrm{~km}^{3}\right)$, (Berrocal et al., $1978)$ and during the Mount St. Helen landslide $\left(2.5 \mathrm{~km}^{3}\right)$ (Kanamori et al., 1984). Deparis et al. (2007) analysed seismograms recorded during rock-falls in the Western Alps by the French permanent seismological network, Sismalp with the aim of getting new information on the rock-fall mechanisms.

A European research project, PRediction Of The Erosion of Cliffed Terrains (PROTECT), was developed to provide large scale monitoring tools to predict costal cliff collapses. A research site located at Mesnil-Val, Haute Normandie, France was selected to test geotechnical and geophysical monitoring systems. A micro-seismic network composed of five sensors (geophones and accelerometers) was deployed at the research site. Results showed the ability of the microseismic network to record signals induced by cracking in the chalk rock-mass and to detect micro-seismic signals prior to a rock-fall (Senfaute et al., 2003, 2005). The analysis of the statistical pattern before the rock-fall showed that a power law acceleration of seismicity rate and energy could be defined on three orders of magnitude, within $2 \mathrm{~h}$ of the collapse time. Simultaneously, the average size of the seismic events increases towards the time to failure (Amitrano et al., 2005). This paper analyses the precursory micro-seismic signals recorded prior to the rock-fall using specific processing methods (i.e. doublets techniques or multiplet selection method) to produce a better understanding of the failure mechanisms and the failure process evolution preceding final failure. The analysis has been conducted on the 224 microseismic events recorded at the Mesnil-Val research site prior to a rock-fall that occurred at the centre of the monitored cliff.

\section{Geological setting of the research site}

The coastal recession from Criel sur Mer to Le Tréport (including the Mesnil-Val research site) (Fig. 1) was estimated to be $0.13 \mathrm{~m} /$ year between 1966 and 1995 (29 years) (Costa et al., 2004). At Mesnil-Val, the coastal cliffs are near vertical, about $50 \mathrm{~m}$ high and cut in the Upper Cretaceous Chalk of the Anglo-Paris Basin, along a NNE-SSW oriented coastline, bordering the eastern English Channel (Fig. 1). The coastal chalk cliffs of Normandy are regularly cut by largescale transverse dry valleys, easily visible on Fig. 1 where Mesnil-Val village is located in the dry valley and extends to the top of the cliff.

The entire cliff face is composed of the Lewes Nodular Chalk Formation dating from the Upper Turonian to Lower Coniacian (Mortimore, 2001). The Lewes Nodular Chalk is a nodular yellowish coarse chalk, including soft, marly bands and nodular hardgrounds, with regular flint layers (Mortimore and Pomerol, 1987; Bristow et al., 1997) (Fig. 2). 


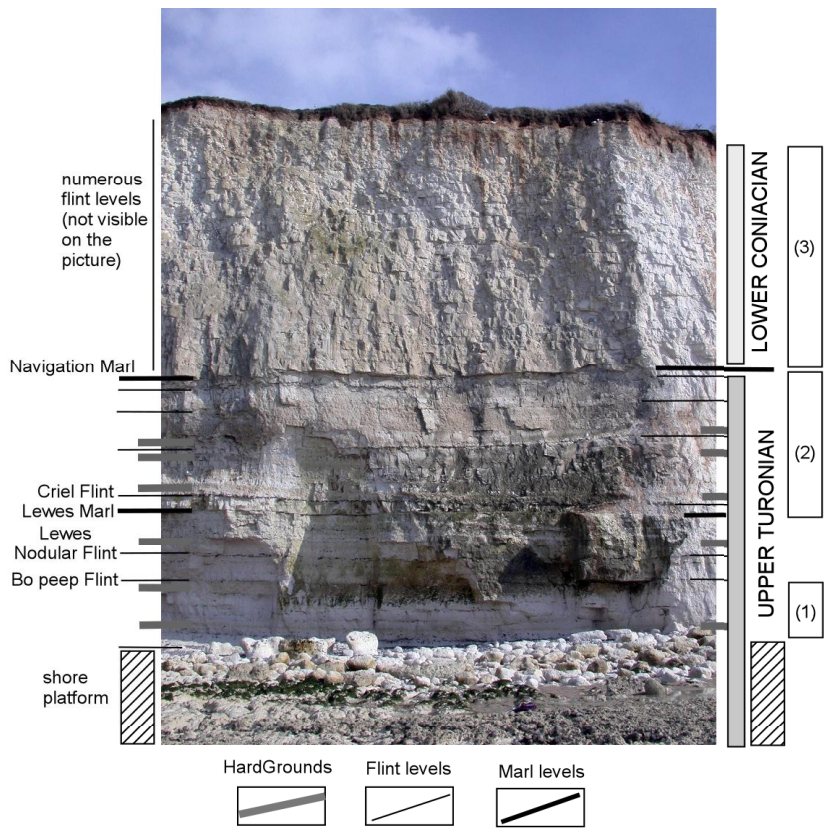

Fig. 2. Lithostratigraphy of the chalk cliff face at Mesnil-Val, Haute-Normandie, France. Specific key-markers, as marl and flints levels are deduced from detailed sections established in the chalk of Sussex (UK) (Mortimore et al., 2001). The cliff is composed of The Lewes Nodular Chalk Formation. See explanations in the text for numbers signification.

At Mesnil-Val stratigraphic investigation identified subhorizontal beds of Upper Turonian chalk exposed in the beach platform and cliff base, with the occurrence of the Mers Hardgrounds, a condensed and hard section of Lewes Nodular Chalk which corresponds to the Kingston Beds in the UK stratigraphy. Many of the marls and flints at this level coalesce due to the condensed nature of this section but the Bo-Peep Flint Band, Lewes Nodular Flint Band, Lewes Marl and the overlying associated Criel Flint Band are all recognisable (Fig. 2). The Navigation Marl marks the stratigraphic limit between Turonian and Coniacian (Mortimore et al., 2001) and outcrops in the lower third of the cliff at about $10-20 \mathrm{~m}$ high. The upper part of the cliff $(2 / 3$ of the total height) is dated Lower Coniacian, from the Navigation Marl up through several identifiable beds to at least the level of the Light Point Hardgrounds (Mortimore and Pomerol, 1987).

As observed in Fig. 2, (1) the first 5-10 m of Upper Turonian chalk on the sea cliff appears as smooth and white due to the regular wash effect of sea water at the base of the cliff. (2) The Lewes Nodular Chalk located between Lewes Marl and Navigation Marl (Upper Turonian, The South Street Beds and Navigation Beds) appears as a weak and white-coloured layer that produces a clear indentation in the cliff and can be recognized for many kilometres along the cliff from MesnilVal to Le Tréport (Fig. 1). Many of the flint bands, hardgrounds and marl seams in the Lewes Nodular Chalk act

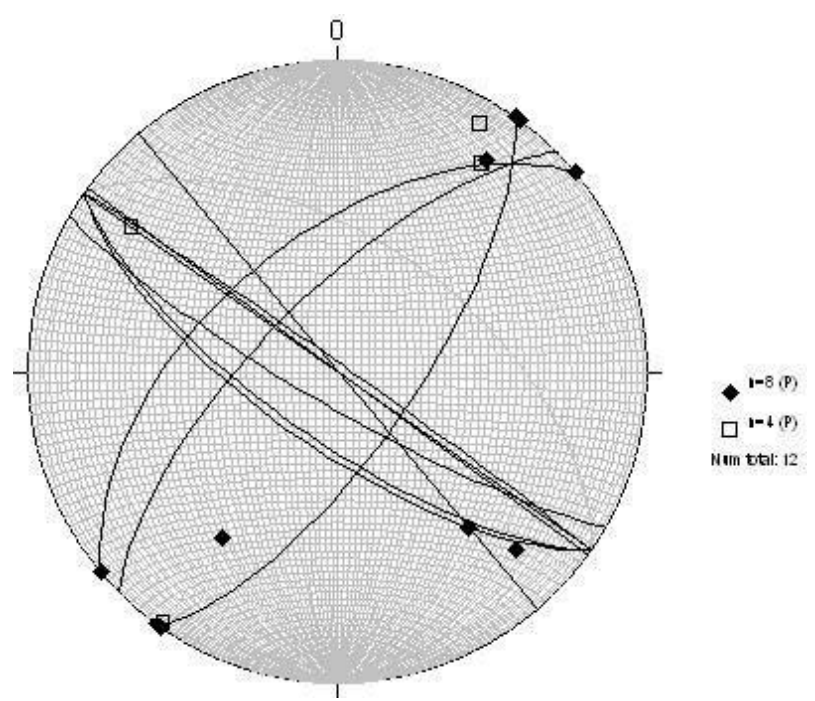

Fig. 3. Cartographic traces of fracture data recorded at Mesnil-Val, using stereonet software, Schmidt projection, lower hemisphere. 12 fracture data planes are shown, with 4 normal faults (poles are represented with white squares) and 8 master-joints (poles are represented with black losanges).

as laterally continuous horizontal layers which have much lower porosity and permeability where perched water tables have developed and their associated karstic features such as dissolution tubules (Lamont-Black and Mortimore, 2000; Mortimore, 2001; Duperret et al., 2002). This regular indentation of the cliff may thus be interpreted as an area preferentially altered and eroded by local denudation processes, due to the natural water accumulation in the chalk located above the Lewes Marl, as proved by the very continuous and clear concave indentation located between the Lewes Marl and the Criel Flint Band. (3) The Lower Coniacian, Lewes Nodular Chalk Formation present above the Navigation Marl is characterised by sub-horizontal nodular flint bands running parallel to bedding and so are laterally continuous and stratigraphically identifiable. The fracture network in this part of the cliff is composed of cubic, sub-vertical fractures with a persistence normally confined to the bed.

Fracture acquisition data were collected along the base of the coastal cliff face and beach platform. It identified two main fracture sets of vertical to sub-vertical normal faults and master-joints oriented N120-130E and N30-50E (Fig. 3). The faults and master joints are often persistent over the entire height of the cliff and along their trace are areas with voids of several decimetres in length with apertures of several centimetres wide, infilled with debris like crushed chalk materials, sands or products of chalk alteration (clays) (Fig. 4). Also vertical joints (of about $1 \mathrm{~m}$ in amplitude) can be observed in the cliff face, but were not systematically measured. These joints have millimetric aperture, without clay or flint infill. 


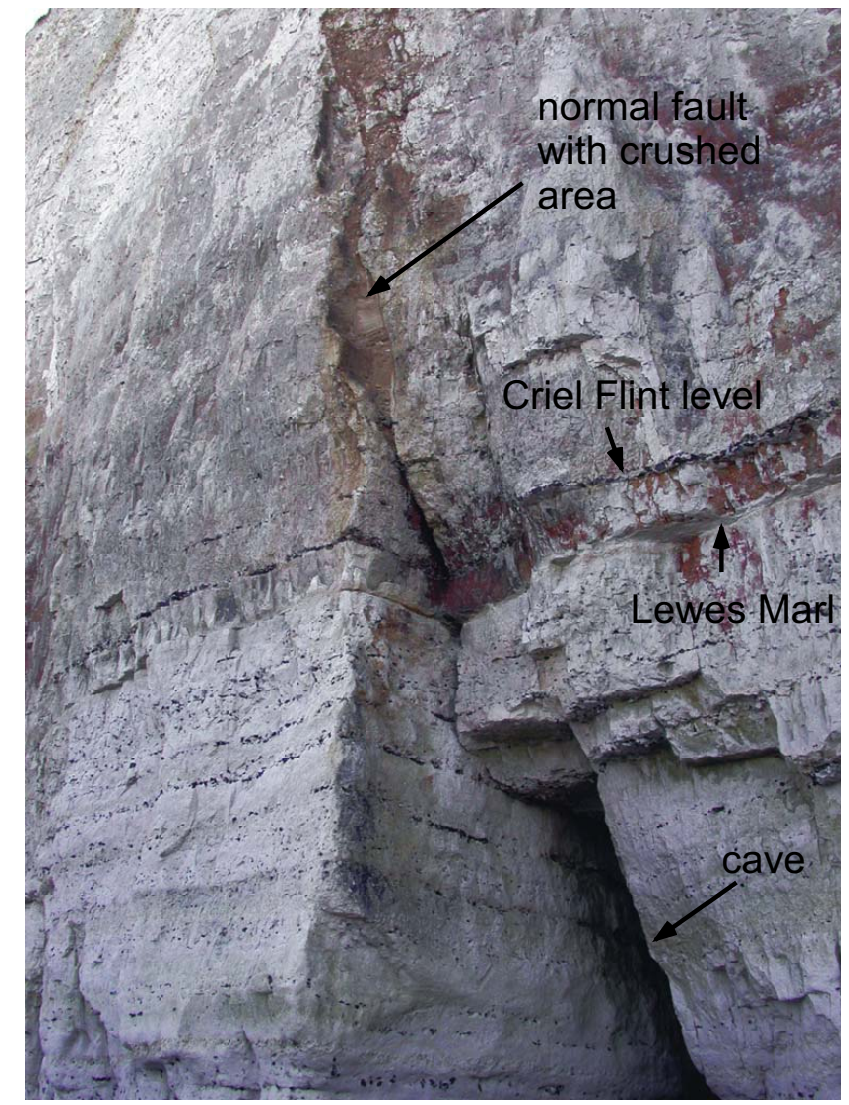

Fig. 4. Detail of a normal fault, with cave development at the base and crushed area above with clays, sands and crushed chalk. The Lewes Marl and Criel Flint are easily recognisable.

Master-joints extend over the entire cliff height, with no apparent displacement. Some of the observed faults show vertical displacements of several centimetres up to $1 \mathrm{~m}$, they are normally faulted. Surprisingly, there is no evidence of strike-slip faulting at Mesnil-Val, however some strike-slip faults have been reported to the southwest at Criel sur Mer near the large-scale Bray Fault system (Fig. 1). The coastline orientation is NNE-SSW, one fracture set is oriented perpendicular to the cliff face (N120-130E) whereas the other one is sub-parallel to the cliff face (N30-50E). In some parts of the cliff face, a N30-50E fracture set is superimposed with evidence of local fracture decompression that may delineate unstable wedge blocks of small size.

\section{Cliff collapses characteristics at Mesnil-Val research site}

Field work at the Mesnil-Val research site has shown a large diversity of collapse processes, due to various triggering processes and variations in the chalk stratigraphy, rock-mass properties and fracture network. Most common events were block falls of small size, i.e. single-blocks of chalk $50 \mathrm{~mm}$ to
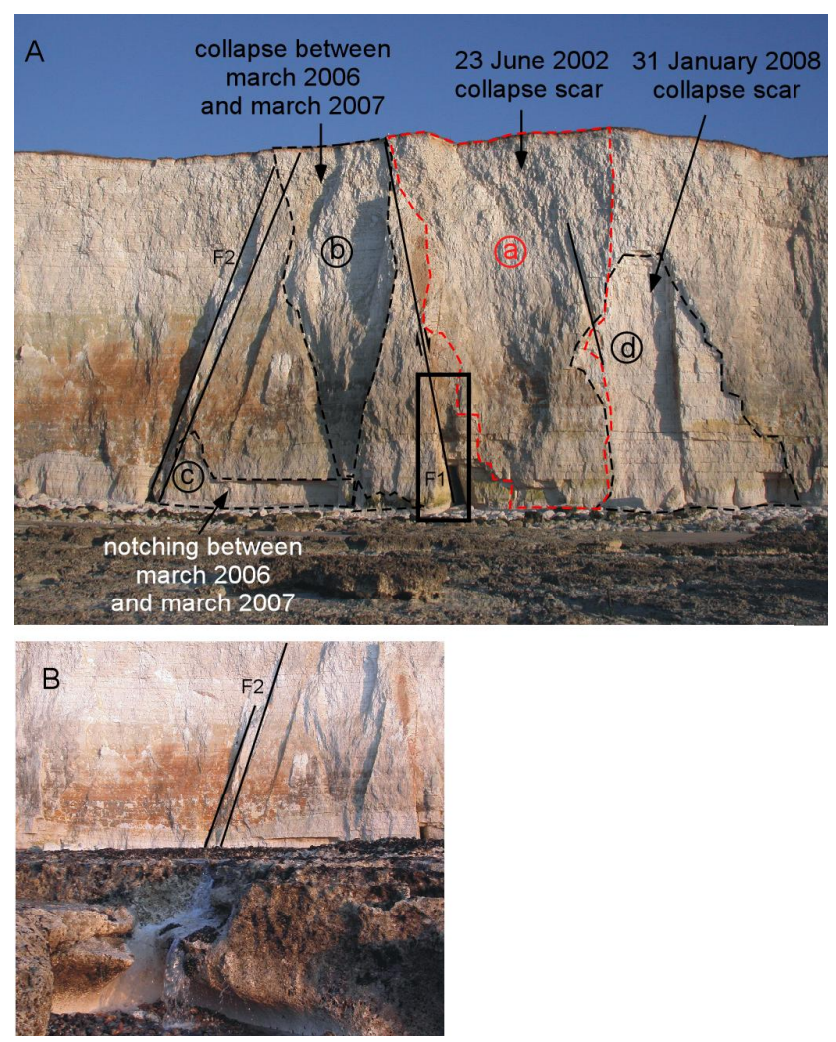

Fig. 5. Cliff surface observations at Mesnil-Val. The picture was taken the 7 April 2008.

$150 \mathrm{~mm}$. They represented $99 \%$ of the events observed during a 3 month winter period (December 2005 to March 2006) with a total eroded volume of about $400 \mathrm{~m}^{3}$ (Dewez et al., 2007). Many of the small blocks failed from the Lewes Marl level, located in the lower part of the cliff (Fig. 2) which has led to the formation of the well marked cliff indentation in the lower part of the cliff, confirming the presents of a perched water table and fresh water flow at this level. The increased failures at this level were due to increased freeze-thaw during the winter and subsequent localised flaking and denudation of the chalk.

Larger cliff collapses varied between several hundred and several thousand $\mathrm{m}^{3}$. These collapses generally occurred as thin slices (a few meters) and extended over the entire cliff height or could be restrained to part of the cliff, typically the base where they are referred to as marine notches. Marine notches develop discontinuously at the base of the chalk cliff and can be several meters long, $1-2 \mathrm{~m}$ high and are typically less than $1 \mathrm{~m}$ deep in depth (Fig. 5a).

The Mesnil-Val research site is characterized by the intense activity of cliff erosion, with numerous cliff collapses of various sizes, observed at various times of the year. A nonexhaustive report of events is given as follows (Fig. 5a): the 23 June 2002 collapse occurred on the instrumented part of the cliff (this study) (Senfaute et al., 2003), another collapse 
occurred in March 2006 (Dewes et al., 2007), several collapses were identified in 2008 with two very large collapses on the 10-11 March 2008 (Fig. 6). The first collapse had a estimated $70-80000 \mathrm{~m}^{3}$ of collapse material and the second failure $20-30000 \mathrm{~m}^{3}$ (Fig. 6). As observed on Fig. 6, the March 2008 collapses involved two portions of the cliff, each part of a local headland. Each collapse was laterally bound by large master-joints oriented N125E $55 \mathrm{~N}$, perpendicular to the cliff face, whereas the two rupture surfaces were located on master-joints oriented sub-parallel to the cliff face (N50E $55 \mathrm{~N})$. This suggests that N50E fracture set favours failures planes and the N120E fracture set acts to laterally bound the extent of the failure propagation. In this case, large-scale cliff collapses were guided by two pre-existing sets of cross fracture families that bound large wedges of chalk rocks that were kinematically able to fail.

As observed on oblique aerial photographs taken in 1986 the largest collapses occur rarely, no large collapses were observed between 1986 and 2008 at this location (22 years). The volume-frequency distribution of rock-falls has been studied by some authors in various contexts, such as continental cliffs (Wieczorek et al., 1992; Hungr et al., 1999; Dussauge-Peisser et al., 2002; Hantz et al., 2003) or in coastal cliffs context (Duperret et al., 2004; Teixeira, 2006; Marquez, 2006). The cumulative distribution of rock-fall volumes always follows a power-law in a volume range covering at least 4 orders of magnitude, with a large number of small events and rare events of large size (Hantz et al., 2003). Observations conducted at the Mesnil-Val research site appear to follow this power-law distribution in time and volume.

\section{Micro-seismic instrumentation developed to investigate the cliff at Mesnil-Val research site}

Micro-seismic systems have been used effectively to detect cracks and subsequent related rock falls in deep coal mining (Mendecki, 1993; Senfaute, 1995; Senfaute et al., 1997; Sato et al., 1998; Iannacchione et al., 2005; Driad-Lebeau et al., 2005) and in abandoned mines (Senfaute et al., 2000; AbdulWahed et al., 2001). However the micro-seismic monitoring systems currently being used in deep mines need adapting for use on natural sea cliffs, because the overburden stress induced by the rock mass is lower than in deep underground mines, thus the signal attenuation is greater and signal disturbance noise is higher along the cliffs located on the coast. The wavelength of the seismic signal which could be recorded during the rupture of a chalk rock-mass was not known and so the use of sensors with broad frequency bandwidth was required. Two types of sensors were selected: geophones with a frequency-band between $40 \mathrm{~Hz}$ and $1.5 \mathrm{kHz}$ and accelerometers with a frequency-band between $2 \mathrm{~Hz}$ and $10 \mathrm{kHz}$, which made it possible to monitor a broad frequency band-width coverage with a good sensitivity. The frequency
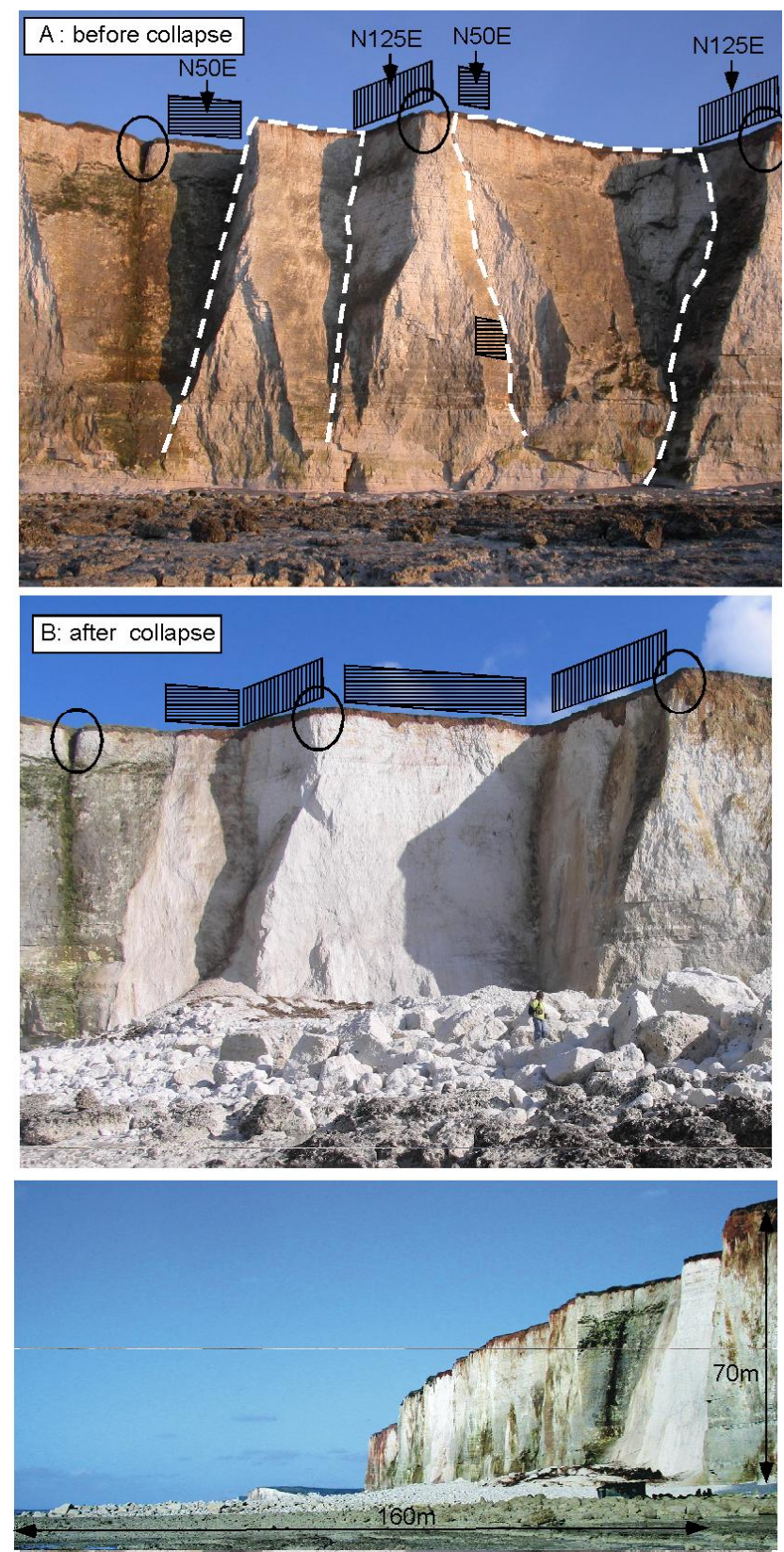

Fig. 6. Photographs of the large scale collapse, 10-11 March 2008 at Mesnil-Val (volume estimated at about $70-80000 \mathrm{~m}^{3}$ ). Black circles on the photographs are common points to compare the two pictures. (A): Photograph taken before the cliff collapse (22 March 2007). (B): Photograph taken just after the cliff collapse (7 April 2008) (C): Profile view of the collapsed chalk material. The landslide extends about $150 \mathrm{~m}$ long the shore platform.

sampling and duration of time recording were $10 \mathrm{kHz}$ and $0.35 \mathrm{~s}$ respectively. Each micro-seismic station contained two types of sensor: a geophone and an accelerometer (see Fig. 7b). 


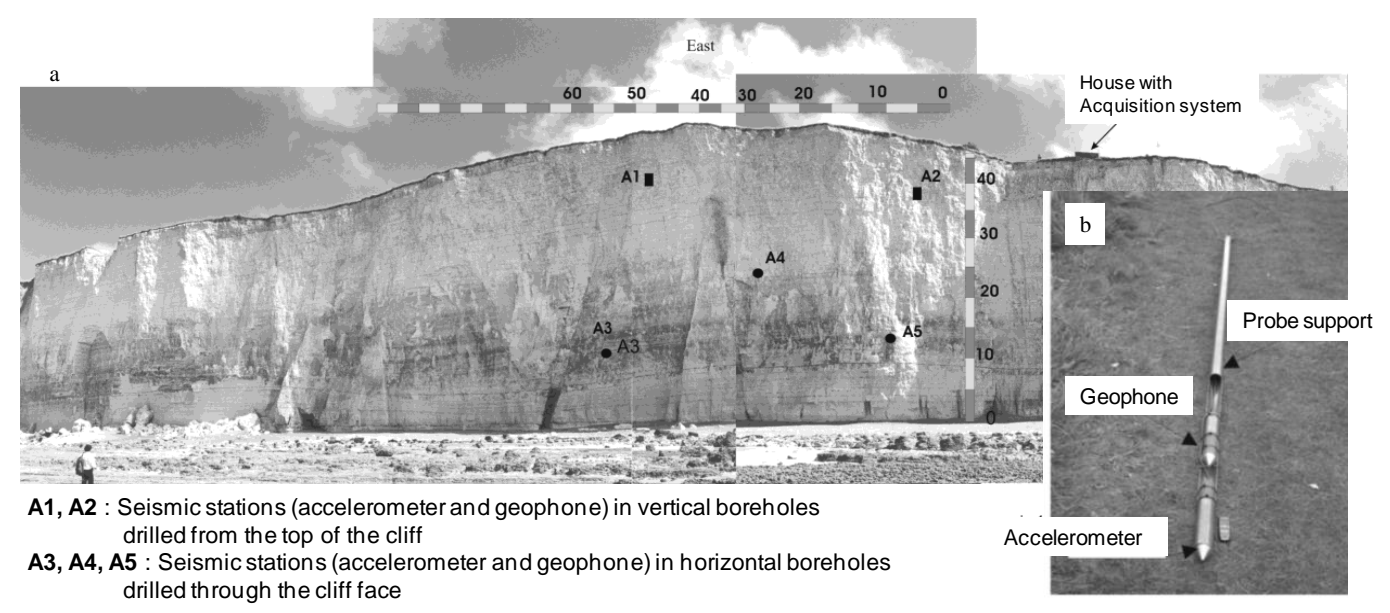

Fig. 7. (a) Location of micro-seismic network installed at Mesnil-Val research site (b) Example of the micro-seismic station composed of a accelerometer and geophone sensors installed in the vertical boreholes (A1, A2) and horizontal boreholes (A3, A4, A5).

The micro-seismic network was installed in the MesnilVal cliff section in 2002 and consisted of five monodirectional micro-seismic stations. Anticipating a strong attenuation of the signal in chalk a maximum of $50 \mathrm{~m}$ spacing between sensors was chosen. The final design of the network had the following characteristics (Fig. 7):

- 2 stations in vertical boreholes, drilled from the top of the cliff, located $10 \mathrm{~m}$ from the cliff edge, to a depth of $10 \mathrm{~m}$;

- 3 stations in horizontal boreholes, drilled through the cliff face to a depth of $6 \mathrm{~m}$.

The sensors were put in the boreholes and cemented in place. After cementing each station was connected to a data acquisition system.

\section{Data recorded and analyses}

The Mesnil-Val research site was monitored for a period of 24 months, between January 2002 and February 2004. Significant micro-seismic activity was recorded during this monitored period. The first difficulty in analysing the microseismic data recorded concerned the tide effect. The sea waves impacted the cliff during the high tide periods (twice each day) and generated a constant triggering of microseismic events. Figure 8 shows the correlation between the number of micro-seismic events recorded and the tides. It can be seen that there was a strong correlation between periods of high tide and the micro-seismic events triggered, the highest tide coefficients, upper around 50, were associated with a large number of micro-seismic events, over 2500 events could be recorded during two hours at high tide. For a tide coefficient under 50 during periods of low tide there were fewer events triggered, only 848 events were recorded during the entire monitored period (24 months). It was possible to assume that these events recorded during the highest tide were directly related to the action of the tide on the cliff face, and interpreted that sea waves induced dynamic impacts on the cliff face that seem to be directly responsible for the micro-seismic events triggered. Thus, only the microseismic events recorded during the low tide period can be linked to mechanical changes within the rock-mass. Therefore, this study will concentrate on the micro-seismic population recorded only during the low tide periods.

The second difficulty in analysing the micro-seismic data concerns the strong attenuation of the micro-seismic signals recorded. Most micro-seismic events triggered were only recorded by one station and only a few events signals were recorded by more than one sensor (Fig. 9). Several blast tests using explosives were conducted for quantifying the signal attenuation level. Forty-eight geophones were laid out in a line parallel to the cliff edge at $2.5 \mathrm{~m}$ intervals. A total of 29 dynamite shots were fired as seismic sources, 22 were on the cliff top and 7 on the wave cut platform at the base of the cliff. Figure 10 shows an example of the typical signals recorded during blasting. The amplitude attenuation was calculated using the correlation between the maximum amplitude of the total signal recorded after each blasting and the distances of blasting and the sensors. This correlation showed that after $30 \mathrm{~m}$ the amplitude of the signal had attenuated by approximately $90 \%$ (Fig. 11). The strong attenuation observed can be related to two main factors: the anelastic attenuation and the geometric expansion. However, the signals recorded from the blasting show a complex waveform without separation of the $\mathrm{P}$ and $\mathrm{S}$ waves (Fig. 10). The explosive (blasting) sources and the short distance between the sensors and the explosive sources explain these waveforms. Due to the type of waveforms it has not been possible to determine what the dominant factor was causing the attenuation of the signal. However, it is likely that the strong signal attenuation was 


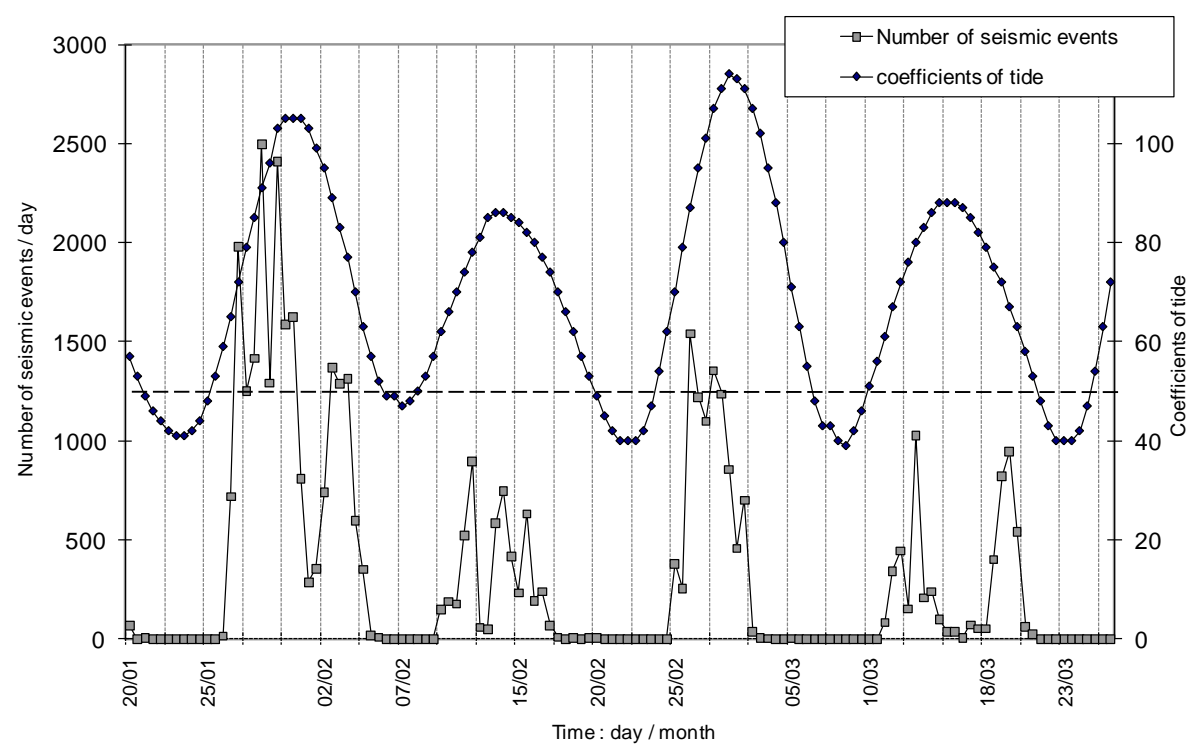

Fig. 8. Correlation between the number of micro-seismic events and the tide periods. For the tide coefficient under about 50 (horizontal dotted line), there are few micro-seismic events recorded.

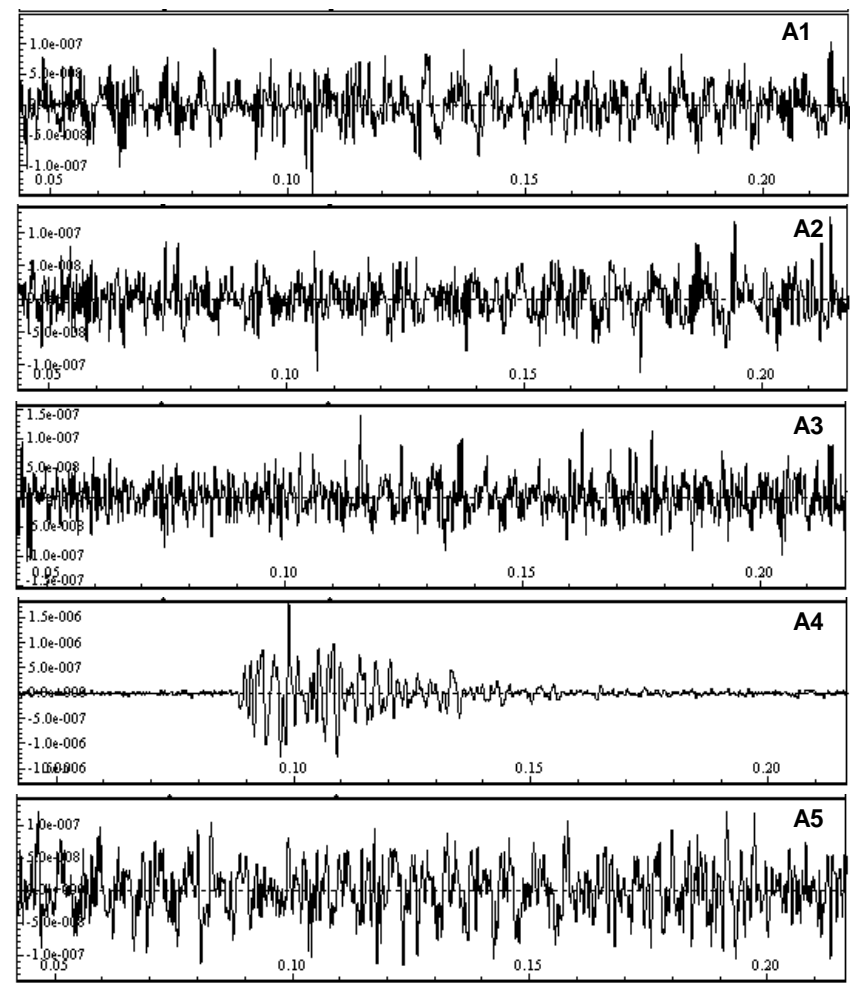

Fig. 9. Example of one micro-seismic event recorded the 23 June 2002 at $3 \mathrm{~h} 45 \mathrm{~min} 41 \mathrm{~s}$ (vertical scale in $\mathrm{m} / \mathrm{s}$ and horizontal scale in second). The seismic signals are recorded by one only sensor (sensor A4 at the example).
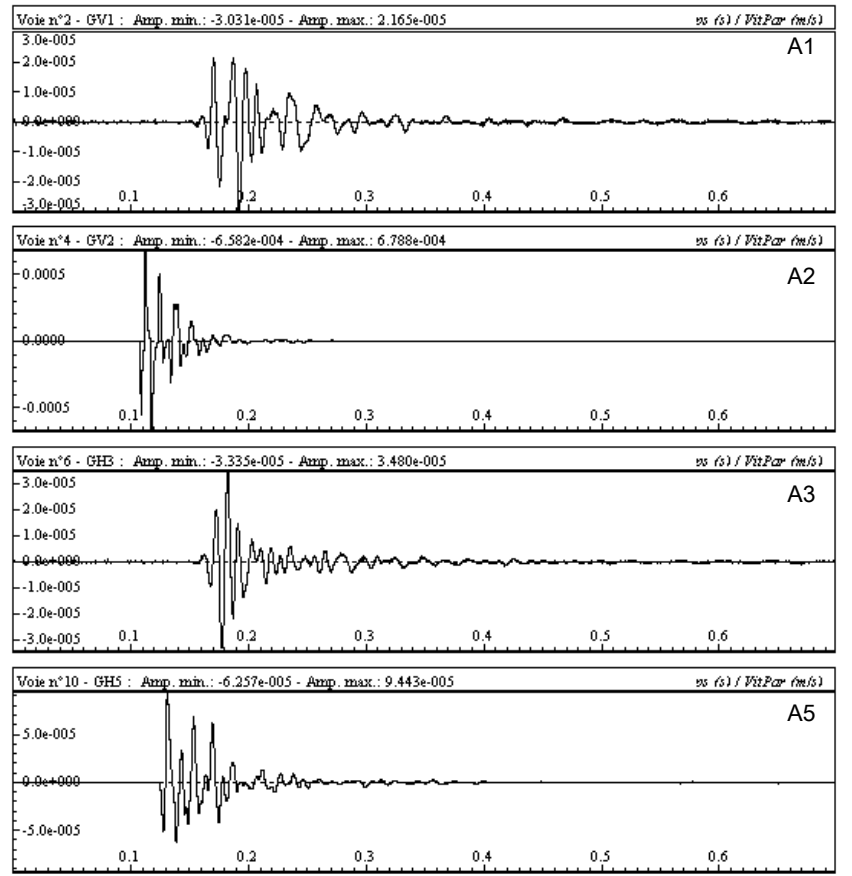

Fig. 10. Example of signals recorded by the sensors A1, A2, A3, A5 during blasting operations. Vertical scale in $\mathrm{m} / \mathrm{s}$ and horizontal scale in seconds. 


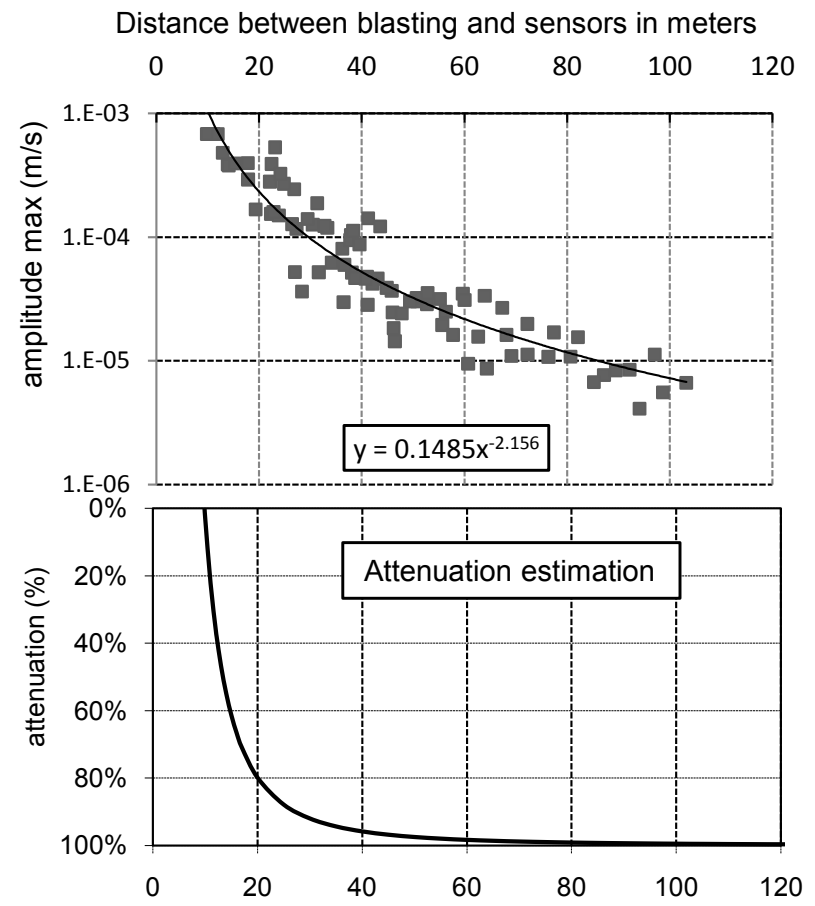

Fig. 11. Amplitudes recorded after blasting at different distances from the stations. These tests demonstrated that after $30 \mathrm{~m}$ from the blasting point the signal amplitude had reduced by approximately $90 \%$.

due mainly to anelastic attenuation induced by the mechanical characteristics of the chalk, in particular the high porosity levels, between $40 \%$ and $46 \%$ in the Lewes Chalk Formation (Duperret et al., 2004; Mortimore et al., 2001) and the high degree of fracturing at the research site.

This test allowed an estimation of the attenuation level generated by the chalk rock-mass which clearly demonstrated the high attenuation of the signals. For a distance of about $20 \mathrm{~m}$ between the blasting source and the sensors the attenuation of the signal was up to approximately $80 \%$. These results explain the fact that the most of the microseismic events were recorded only by one sensor (Fig. 9).

To better take into account the difficulties mentioned above and particularly the problems associated with tidal waves only the micro-seismic population recorded during the low tide periods could be analyzed. During these low tide periods and for the 24 month recording period the total number of micro-seismic events was 848 (Fig. 12a). On the 23 June 2002 a cliff collapse occurred in the centre of the monitored zone at Mesnil-Val research site. The estimated rock-fall volume was between 1000 to $2000 \mathrm{~m}^{3}$ (Fig. 13). During $15 \mathrm{~h}$ prior to the rock-fall and only during the low tide 224 micro-seismic events were recorded by one sensor (sensor A4) located at the centre of the monitored area. Figure 12 a shows that during the 5 months prior to the rock-fall, 343 micro-seismic events were recorded and small anomalies were observed on the 19 February 2002 (36 micro-seismic events recorded in one day) and on the 14 June 2002 (33 micro-seismic events). It is possible that these micro-seismic events were associated with the small detachments of blocks but no evidence of rock-fall was observed at the research site. In the 19 months following the rock-fall a total of 281 microseismic events were recorded.

To perform the analysis of the micro-seismic data ( 848 events recorded only during low tide periods) the seismic energy released by each event was determined as follows:

$$
E=\frac{1}{N k} \sum_{k=1}^{N k} \sum_{j} A_{j k}^{2} \cdot \Delta t
$$

Where $E$ is the signal energy of one micro-seismic event, $N k$ the quantity of channels where the event has been identified, $A j$ the amplitude values at each sampling time between $\mathrm{P}$-wave pick and end-pick in $\mathrm{m} / \mathrm{s}$ using only the amplitude values from the geophones. It was assumed that the signal energy received at the sensors was proportional to the source energy released.

Figure 12b illustrates the cumulative seismic energy released during the monitored period and shows that the microseismic activity was relatively stable during the first 6 months before the collapse on 23 June. Abnormal micro-seismic energy was observed on 23 June and recorded only by one sensor (sensor A4). After the collapse, the seismic energy became stable again until the end of the experiment (February 2004). Figure 14 shows the behaviour of seismic energy released on 23 June. The first series of seismic events occurred at 03:00 h ( $15 \mathrm{~h}$ before the collapse) and were relatively small. The level of seismic energy continued to increase during the day until 16:00 h, when significant increases occurred. At approximately 19:00 h the level of seismic activity increased considerably until the rock-fall occurred at 19:19h.

\subsection{Micro-seismic activity in relation to the rock-fall}

Specific analyses were made to the micro-seismic events recorded $15 \mathrm{~h}$ prior to the rock-fall (224 seismic events, Fig. 14). The doublet technique or multiplet selection method (Got et al., 1994) was applied to the data to identify seismic event families with similar waveforms. A doublet is a pair of seismic events whose seismograms are identical over a wide range of frequencies and a multiplet is a group of similar doublets. The objective of the "doublet method" is to characterise the degree of similarity of a pair of events using the modulus of the coherency spectrum. The assumption is that events giving rise to a doublet or multiplet are similar (Poupinet et al., 1985; Moriya et al., 1994).

Let $S_{1}(t)$ and $S_{2}(t)$ be the ground velocity seismograms of the two events ( 1 and 2 ), recorded at the same point $x$. The events 1 and 2 constitute a doublet, if at any position $\mathrm{x}$ in space, the following equation is satisfied:

$S_{2}(t)=K_{S 1}(t-\tau)$ 

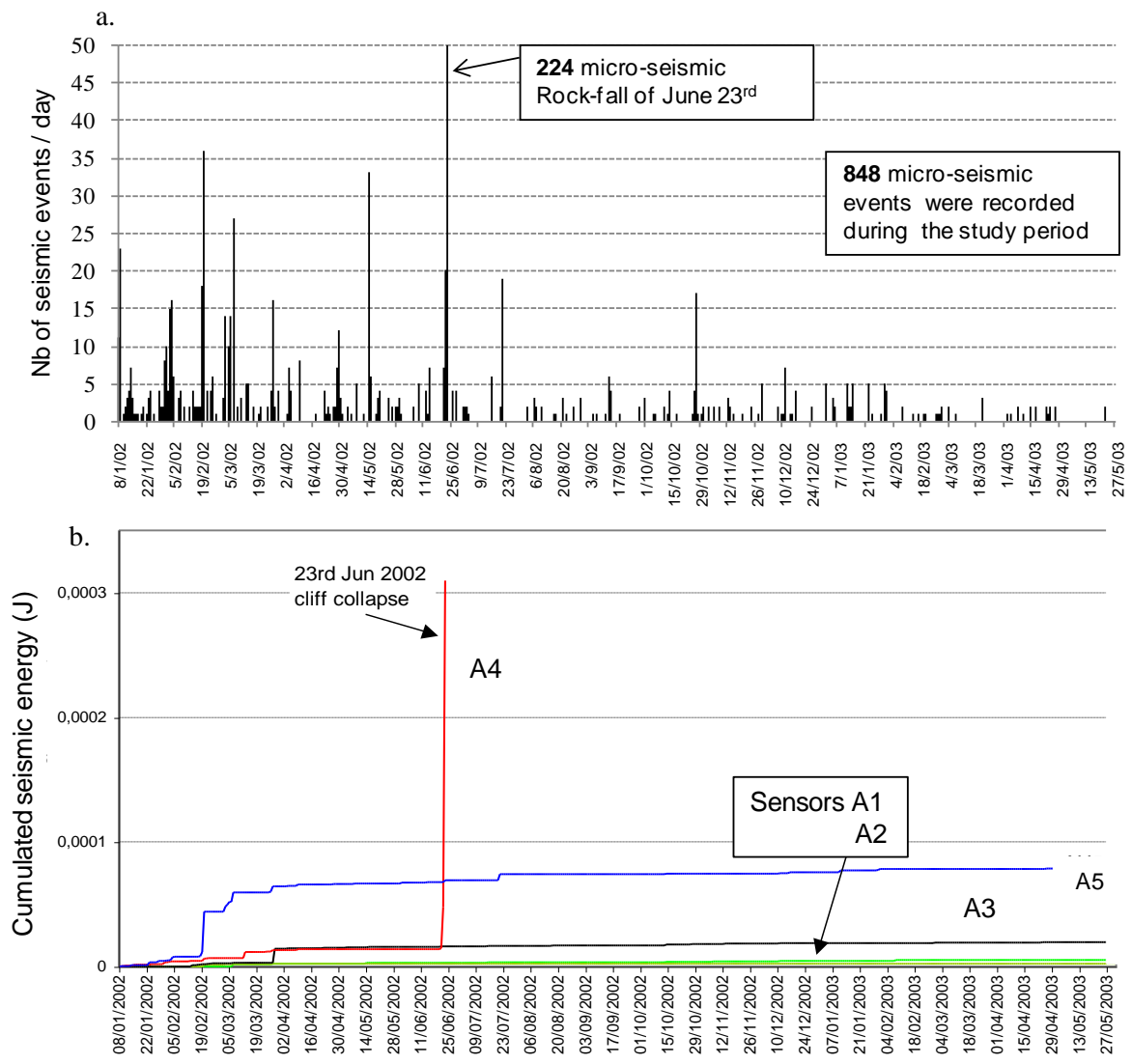

Fig. 12. (a) Number of micro-seismic events per day recorded only during low tides and during 18 months of the monitored period. (b) Cumulative seismic energy evolution per day for each sensor (A1, A2, A3, A4, A5).

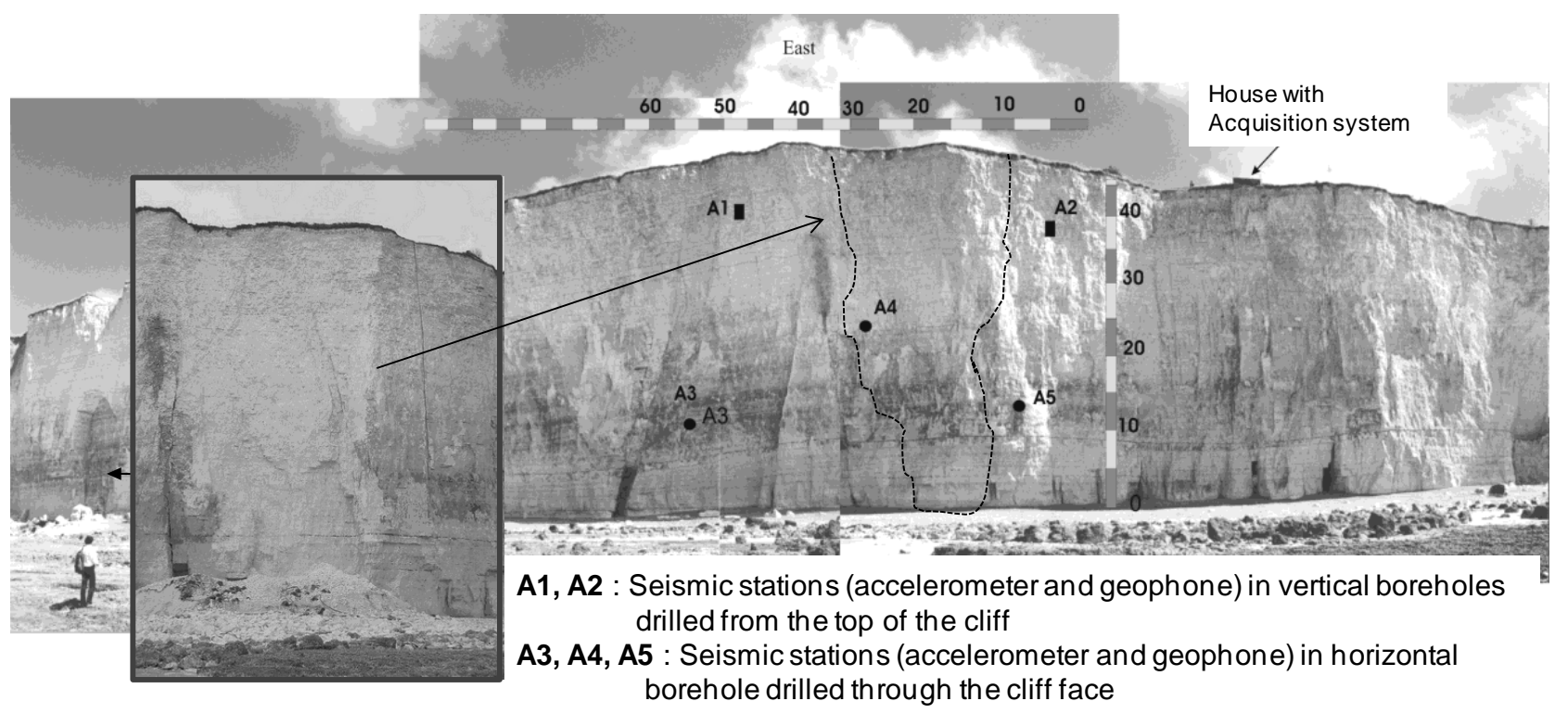

Fig. 13. Rock-fall on the 23 June 2002 occurred at the centre of the monitored zone. The estimated rock-fall volume was around $2000 \mathrm{~m}^{3}$. 


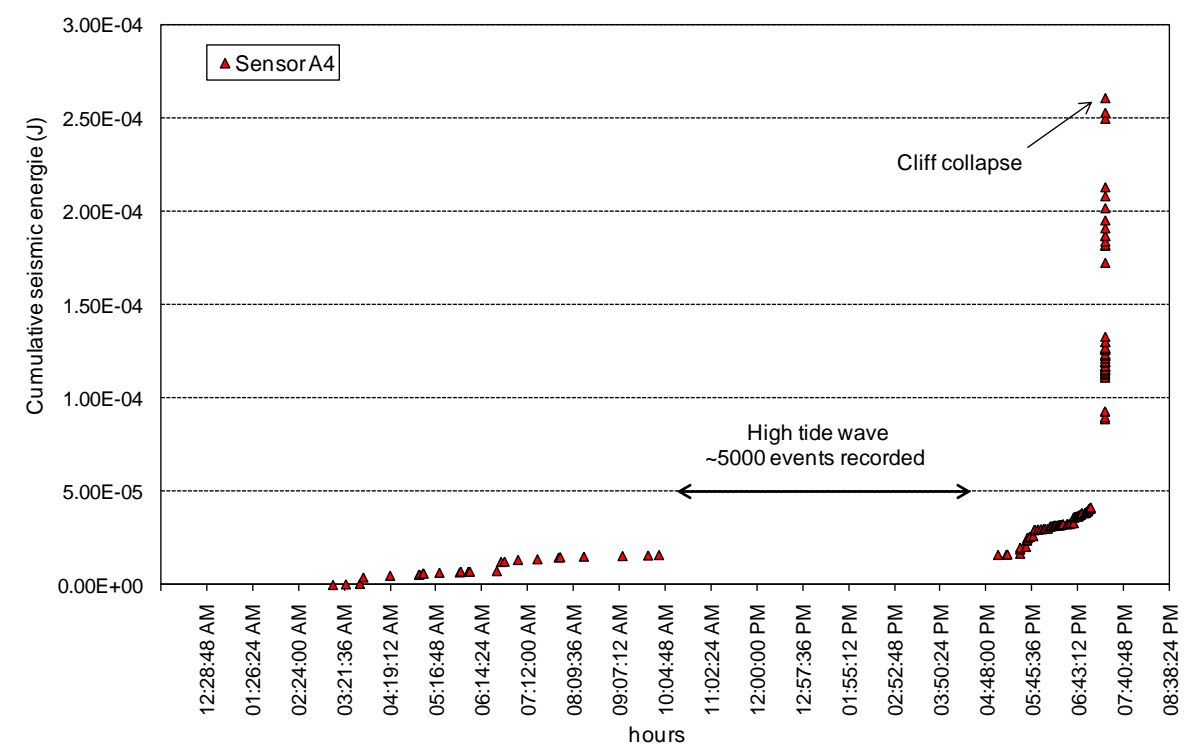

Fig. 14. Cumulated seismic energy by hour of 224 micro-seismic events recorded on 23 June by sensor A4. The micro-seismic events recorded during the high tide period between $\sim 10: 00$ a.m. and 04:48 p.m. have not been analysed.

$\tau$ : time difference at the origin and $K$ : amplitude ratio of the two seismograms.

The "doublet method" is based on the coherence of the signals with respect to the time, but calculations are obtained in the frequency domain using a Fourier transform:

$S_{2}(f)=K S_{1}(f) \exp (2 i \pi f \tau)$

$S_{1}(f)=\int_{S_{1}}(t) \exp (-2 i \pi f \tau) d t$

The spectre of $\gamma_{2}$ and $S_{2}(t)$ is expressed by:

$\gamma_{2}=S_{2}(f) \cdot S_{2}(f)^{*}=K_{2} \cdot\left|S_{1}(f)\right|^{2} \cdot \exp (4 i \pi f \tau)$

The inter-spectre of $S_{1}(t)$ and $S_{2}(t) \gamma_{12}$ is expressed by:

$\gamma_{12}=S_{1}(f) \cdot S_{2}(f)^{*}=K \cdot\left|S_{1}(f)\right|^{2} \cdot \exp (4 i \pi f \tau)$

Then the spectral ratio is given by:

$R_{12}=\frac{S_{1}}{S_{2}}=\frac{\gamma_{12}}{\gamma^{2}}=\frac{1}{K} \cdot \exp (-2 i \pi f \tau)$

The modulus of the spectral ratio is $1 / K$ and its phase is $2 i \pi f \tau$.

Doublet or multiplet selection technique was applied to the 224 micro-seismic events recorded on 23 June, before the collapse. A threshold coherence of $90 \%$ was used. This search produced 59 events in three groups of multiplets or families and 175 events were excluded (not regrouping in a family population). An example of the multiplet waveforms can be seen in Fig. 15. Multiplet event analysis is a common method for calculating the relative source location of similar events. The advantage of using multiplet analysis is that it can evaluate individual fractures, especially those with similar physical characteristics, because the correlation of their waveforms is based on their similarity. The multiplet is most likely the expression of stress release on the same fracture plane, the similar waveforms suggest the same source mechanism (Poupinet et al., 1985).

Figure 16 illustrates the temporal distribution of three multiplets or families and events outside of the family classification. For family 1, that occurs several hours before the rock-fall the signals contained a large frequency spectrum band located between $\sim 100$ and $1000 \mathrm{~Hz}$ (Fig. 17a1, b1). For events in family 2, the frequencies are between 100 and $500 \mathrm{~Hz}$ but the amplitude of higher frequency band between 500 and $1000 \mathrm{~Hz}$ is lower than for family 1 (Fig. 17a2, b2). The events of family 3 occur just before the rock-fall and the higher frequency-band between 500 and $1000 \mathrm{~Hz}$ practically disappear, the spectrum contains only lower frequencies between about 100 and $500 \mathrm{~Hz}$ (Fig. 17a3, b3).

For quantifying these results a Ratio $(R)$ of spectral amplitudes was determined. For each micro-seismic event regrouped in families, $R$ is calculated as follows:

$R=\mathrm{MA}_{(100 \mathrm{~Hz}-500 \mathrm{~Hz})} / \mathrm{MA}_{(500 \mathrm{~Hz}-1000 \mathrm{~Hz})}$

$\mathrm{MA}_{(100 \mathrm{~Hz}-500 \mathrm{~Hz})}$ : Maximum Amplitude of frequency-band between $\sim 100 \mathrm{~Hz}$ and $500 \mathrm{~Hz}$.

$\mathrm{MA}_{(500 \mathrm{~Hz}-1000 \mathrm{~Hz})}$ : Maximum Amplitude of frequencyband between $\sim 500 \mathrm{~Hz}$ and $1000 \mathrm{~Hz}$.

For each family the average ratio $R$ is: $R$ (family 1 ) $=1.5 \pm 0.08 ; R$ (family 2 ) $=2.7 \pm 0.32$ and $R$ (family 3$)=7.1 \pm 0.68$. These results show that family 3 , just before the rock-fall, has a ratio $R$ about 4 times higher 

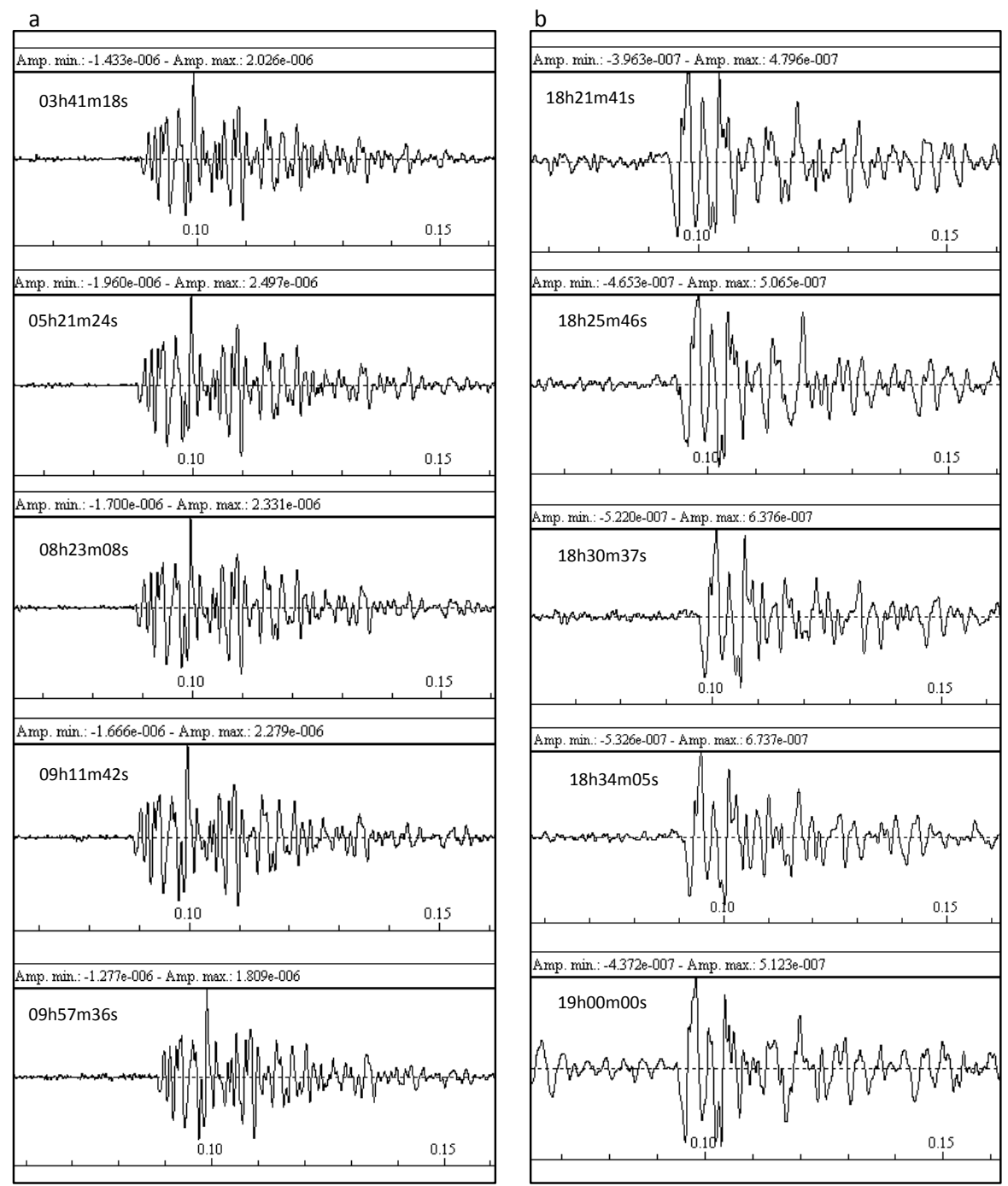

Fig. 15. Example of multiplet waveforms recorded before the rock-fall at the station V4. (a) waveforms of the family 1; (b) waveforms of the family 2. Horizontal scale in seconds. Vertical scale in $\mathrm{m} / \mathrm{s}$.

than the $R$ of family 1 implying progressive decrease of the Maximum Amplitude of the frequency-band 500-1000 Hz. Immediately after the events of family 3 , all stations recorded a new type of signal which contained a very low frequency spectrum (below than $100 \mathrm{~Hz}$ ) for a duration of approximately $10 \mathrm{~s}$ (Fig. 18). These new signals were clearly associated with the vibration induced by the shock of the detached rock-mass impacting on the ground.

\section{Discussion}

Geological observations of the cliff face indicate the occurrence of numerous hard ground levels, marl seams and flint layers in the lower part of the chalk cliff (Fig. 2). At a small scale, these variations produce heterogeneous mechanical behaviour of the cliff. Structural observations conducted on the 23 June 2002 collapse scar (Fig. 5) does not indicate the occurrence of large scale fractures within the scar. Only small scale joints appear in the upper part of the scar, with a similar orientation of the main fracture family highlighted in Sect. 3 and Fig. 6 (N120E). The cliff collapse was not controlled by pre-existing large scale fractures but by small scale bed bound fractures running sub-parallel to the cliff orientation. Moreover, the occurrence of a major normal fault with clay infill, bounding the cliff collapse to the left had no influence on the cliff collapse initiation, but acted as a boundary on the lateral extent of the failure.

The analysis of the micro-seismic signals recorded prior to the 23 June 2002 cliff collapse at the Mensil-Val research site identified several different phases of failure mechanisms. The most important phases concern the failure process associated with event families identified by the multiplet selection method. 


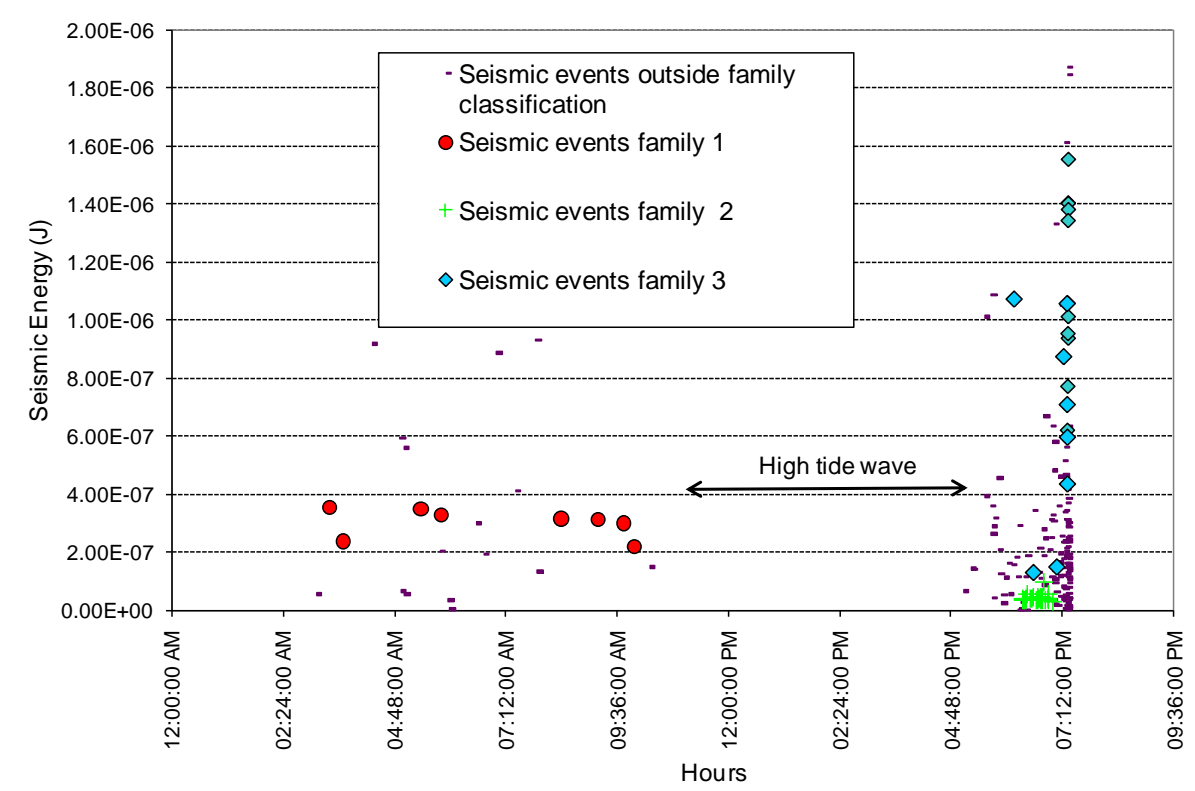

Fig. 16. Temporal distribution of the multiplet gathered into 3 families and micro-seismic events outside family classification. The seismic events recorded during the high tide period ( $\sim 5000$ events) were not processed.

The first failure mechanism phase was initiated about $15 \mathrm{~h}$ prior to the rock-fall and was associated with the micro-seismic events of family 1 , characterised by the highest frequency spectrum. The evolution of failure mechanism process is associated with the others families identified some hours later and just before the rock-fall (families 2 and 3). The micro-seismic events of family 2 occurred several minutes before the rock-fall and were characterised by a lower frequency spectrum than that of family 1 . For family 3 that occurred just before the rock-fall the higher frequencies disappeared and the spectrum was only composed of low frequency micro-seismic events (Fig. 17).

The clear decrease of the frequency spectrum observed from the micro-seismic events regrouped in families could be attributed to two concurrent phenomena: attenuation of the signal and/or source effects as was discussed by Ohnaka and Mogi $(1981,1982)$. These authors investigated the frequency dependence of acoustic emission rates under incremental uniaxial compression tests of rocks in the laboratory. Ohnaka and Mogi $(1981,1982)$ identified that when the existing micro-cracks grow and develop (or coalesce) to larger fractures it tends to generate micro-seismic events with larger amplitudes and containing lower-frequency components; for these authors the frequency characteristics of acoustic emissions were used to characterise the micro-fracturing processes leading to final failure. However, Ohnaka and Mogi (1982) also suggested that when micro-fractures were widely developed, the emission events with low frequencies wave components became more detectable and the higher-frequency wave components were more highly attenuated as they propagated away from the source. Nishizawa et al. (1981) showed that as the rock approached failure the attenuation increased most strongly at higher frequencies, thus it can be expected to see only the lower frequencies immediately prior to a cliff collapse. Both explanations may be partly responsible for the frequencies observed although it is difficult to determine in quantitative terms to what extent each is responsible (Ohnaka and Mogi, 1982). Using the scanning electron microscope Tapponier and Brace (1976) and Kranz (1979) examined how fractures grow, develop, and interact in rocks under compression and suggested that fracture interaction and coalescence are important before macro-fracturing occurred and that the larger fractures increase as the rock approached the final failure. They also observed healed pre-existing fractures and suggested that rupturing of some of these healed portions and of asperities on the pre-existing fracture surfaces could contribute to generate higher frequencies. The models proposed by Ohnaka and Mogi (1981, 1982), Tapponier and Brace (1976) and Kranz (1979) could be applied to the micro-seismic events recorded before the rock-fall at the Mesnil-Val research site. The micro-seismic events grouped in families (families 1, 2 and 3) showed a clear progressive decrease of frequency spectrum as the rock approached final failure. Thus a model of progressive fracture development leading to the cliff collapse on 23 June 2002 can be proposed due to several phases identified, following the model below: 

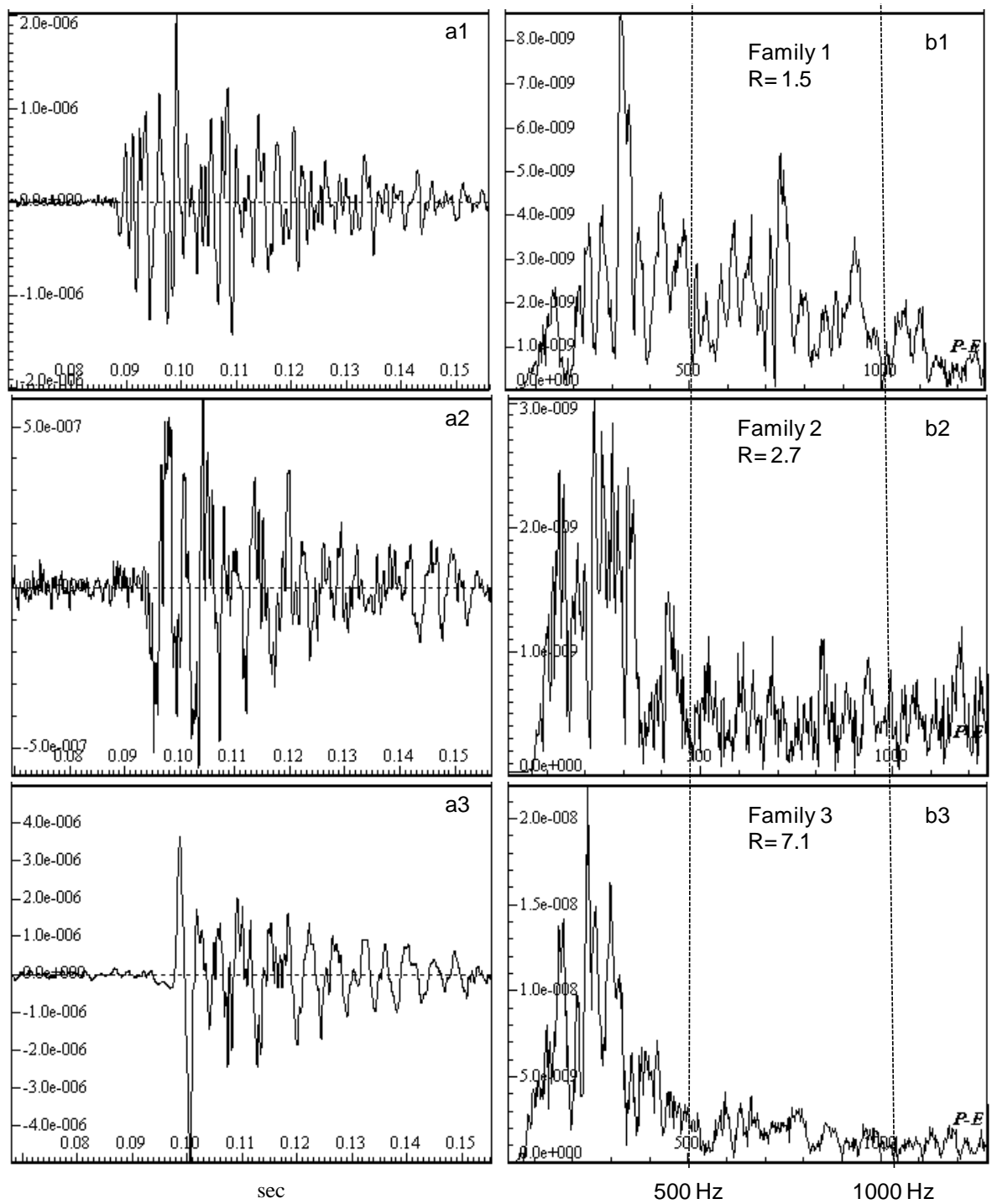

Fig. 17. (a) Example of seismograms (vertical scale $\mathrm{m} / \mathrm{s}$ ) and (b) frequencies spectrum (vertical scale $\mathrm{m} / \mathrm{s} \mathrm{s}$ ) of each micro-seismic events family: a1) seismogram and b1) frequency spectrum of family 1: the signals contain high frequencies in a spectrum-band between $\sim 100$ and $1000 \mathrm{~Hz}$. a2) seismogram and b2) frequency spectrum of family 2: the signals contain lower frequencies than family 1 showing a clear decreasing of the highest frequency components a3) seismogram and b3) frequency spectrum of family 3 occurred just before the rock-fall: the signals contain the lowest frequencies. $R$ is the Ratio of the maximum amplitude of frequency-band $\sim 100-500 \mathrm{~Hz}$ and the maximum amplitude of frequency-band $\sim 500-1000 \mathrm{~Hz}$.

- phase 1: the micro-seismic events of family 1 recorded $15 \mathrm{~h}$ before the rock-fall and characterised by the highest frequency spectrum suggesting a crack initiation mechanism or the opening of existing fractures probably in tension (Tapponier and Brace, 1976; Kranz, 1979);

- phase 2: micro-seismic events of family 2 recorded several minutes before the rock-fall associated with a clear decreasing of the highest frequency components suggest that the mechanism was related to the growing and development (or coalesce) of existing micro-fractures into larger fractures (Ohnaka and Mogi, 1981, 1982);

- phase 3: micro-seismic events of family 3 recorded immediately before the rock-fall, represent a frequency spectrum lower than those of families 1 and 2, the source mechanism could be related to the shearing or opening of the existing fractures inducing final failure processes (Ohnaka and Mogi, 1981, 1982);

- phase 4: the cliff failure occurs, the detached rock-mass falls on the ground. A huge shock impacts the ground 


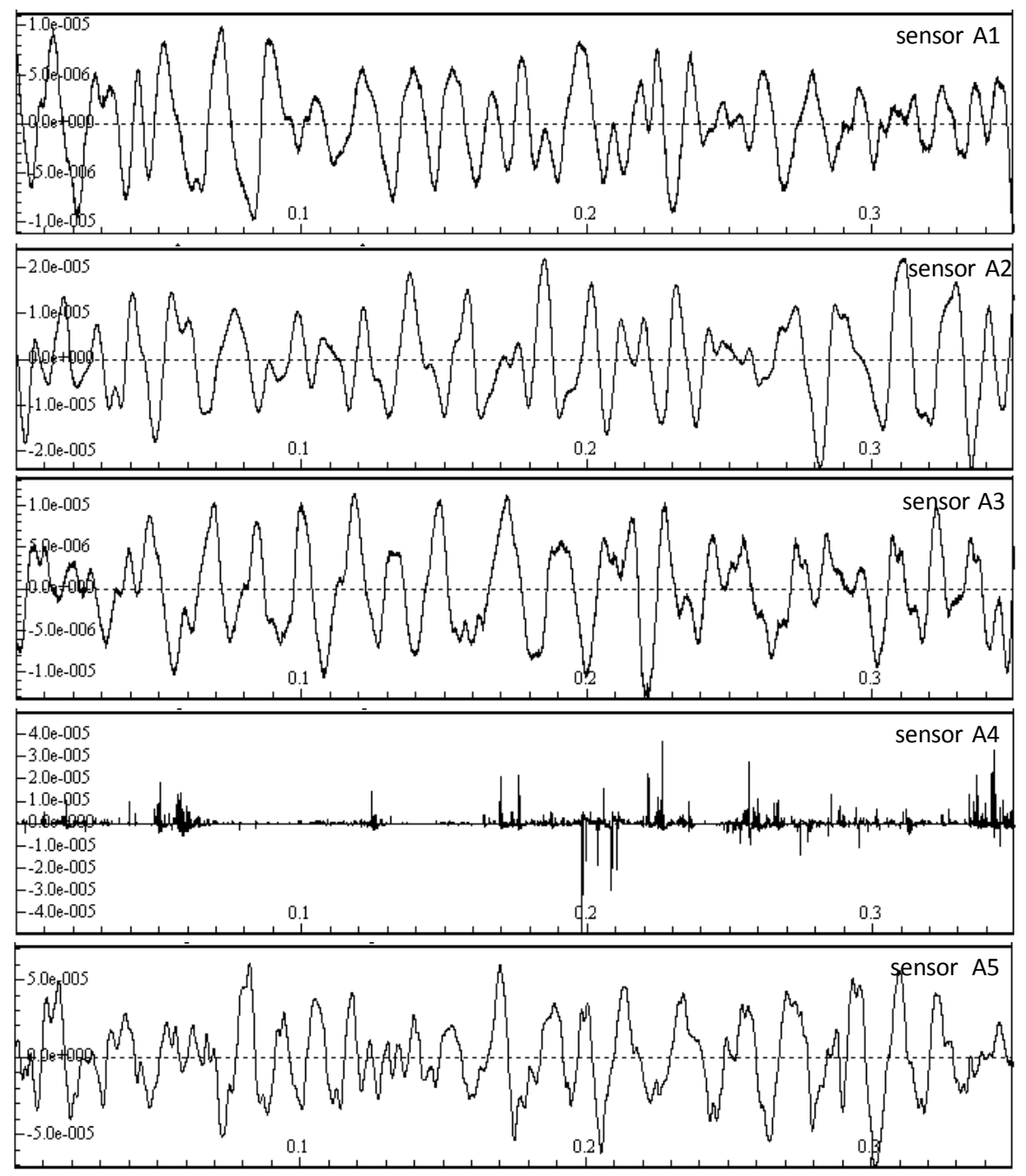

Fig. 18. Example of seismograms associated to the shock of the detached rock-mass on the ground. The total duration of this event was about $10 \mathrm{~s}$. The signals of sensors A1, A2, A3, and A5 are frequencies between $50 \mathrm{~Hz}$ and $100 \mathrm{~Hz}$. For the sensor A4, the cable was broken by the rock-mass detachment, only electrical signals were recorded. The vertical scale is in $\mathrm{m} / \mathrm{s}$ and horizontal scale is in seconds.

and generates seismic waves recorded by all seismic stations (Fig. 18). These signals were clearly associated with the vibration induced by the shock impacting on the ground.

This research has developed an understanding of the failure mechanism processes that occurred prior to the rock-fall on 23 June 2002 at the Mesnil-Val research site. The microseismic records identified the failure initiation mechanisms for small-scale crack and joint propagation rupture processes in the chalk. This process is limited to a rock-fall volume estimated between 1000 and $2000 \mathrm{~m}^{3}$, where collapses are not controlled solely by master joints or faults running sub-parallel to the cliff but by small joints developing and coalescing prior to a collapse. With larger collapses also occurring at the research site, as observed in March 2008 with volumes estimated around $70-80000 \mathrm{~m}^{3}$ and $20-30000 \mathrm{~m}^{3}$ rupture propagation appears to be controlled by joints and master joints, orientated sub-parallel to the cliff face and laterally bound by large-scale fractures running sub-perpendicular to the cliff face. Unfortunately, the micro-seismic system was not working during the large-scale collapses and therefore the behaviour and characteristics of micro-seismic signals that would be recorded in the case of a very large-scale collapse, where rupture initiation occurs on pre-existing large-scale fractures remains unknown. However, Duperret et al. (2004) suggested that the main mechanism triggering cliff failure processes are meteorological (rainfall, temperature), wave action on the shore platform and/or wave impact on the cliff base, cyclical tidal effects and fatigue caused by stress relief. These external mechanisms act on the rock-mass structure to trigger failures. In the case of the 23 June 2002 rock-fall, the tide was low during 
the collapse, which suggests no direct relations between marine action and collapse triggering. As no particular rainfall excess and temperature variations were recorded during this period, a process of decompression fracture initiation may be invoked, probably favoured by fatigue due to cyclic tidal effects and wave impact.

\section{Conclusions}

The seismic sensors installed at the Mesnil-Val research site were able to record micro-seismic signals induced by cracks in the chalk rock-mass. Strong signals were detected by the micro-seismic system approximately $15 \mathrm{~h}$ prior to a rock-fall. The observations and the measurements led to the hypothesis that the rock-fall occurred due to several phases of failure mechanisms. The different phases of the failure process were associated with event families identified by multiplet selection. The micro-seismic events regrouped in families showed a progressively decrease of frequency spectrum as the rock approached final failure and led to the hypothesis that the rock-fall occurred over several phases:

- phase 1: crack initiation and opening or shearing of preexisting fractures characterised by micro-seismic events with the highest frequencies in a broad spectrum-band between $\sim 100$ and $1000 \mathrm{~Hz}$ (family 1);

- phase 2: growing and developing (or coalesce) of existing micro-fractures to larger fractures characterised by micro-seismic events with a clear decreasing of the highest frequency components (family 2);

- phase 3: shearing and/or opening of larger existing fractures permitting the complete detachment of the blocky rock-mass, this was associated with microseismic events of a lower frequency spectrum than families 1 and 2, the highest frequency components were almost absent (family 3);

- phase 4: the rock-fall impact on the ground was characterised by micro-seismic events with a very low frequency spectrum, below $100 \mathrm{~Hz}$.

There are few applications of seismic monitoring system which allow identification of precursory signals before a cliff rock-fall. It is suggested that the present research is one of the first cases allowing a holistic model linking failure mechanism processes that may occur prior to coastal cliff rock-fall to be developed. This work acts as a baseline although it concentrated on the chalk and rock-falls of 1000$2000 \mathrm{~m}^{3}$, the system could be adapted for use on other rock types and should be able to measure any volume of collapse. These encouraging results offer the possibility of using the micro-seismic system to establish coastal cliff monitoring programmes to monitor high risk zones and to further develop research of our understanding of slope failure mechanisms.
Acknowledgements. This work was made possible by funding from the Commission European Community (PROTECT project: EVK3CT-2000-00029), French Ministry Industry and French Ministry Sustainable Development. Thanks to all partners from PROTECT project (R. Mortimore, J. Busby, K. Stone, J. Ch. Gourry) for their scientific collaboration. The INFORM micro-project (INTERREG III funds) was also used to complete structural acquisition on this site and to conduct scientific exchanges on the methodologies used to instrument coastal rock cliffs dedicated to coastal management. We thank J. Busby and an anonymous reviewer for their comments and suggestions helped to improve the quality of the manuscript.

Edited by: V. F. McNeill

Reviewed by: two anonymous referees

\section{References}

Amitrano, D.: Brittle-ductile transition and associated seismicity: Experimental and numerical studies and relationship with the $b$ value, J. Geophys. Res.-Sol. Ea., 108(15), 2044, 2003.

Amitrano, D., Grasso, J. R., and Senfaute, G.: Seismic precursory patterns before a cliff collapse and critical point phenomena, Geophys. Res. Lett., 32(5), L08314, doi:10.1029/2004GL022270, 2005.

Berrocal, J., Espinosa, A. F., and Galdos, J.: Seismological and geological aspects of Mantaro landslide in Peru, Nature, 275, 533536, 1978.

Boatwright, J.: Spectral theory for circular seismic sources - simple estimates of source dimension, dynamic stress drop, and radiated seismic energy, Bull. Seismol. Soc. Am., 70, 1-27, 1980.

Bristow, R., Mortimore, R., and Wood, C.: Lithostratigraphy for mapping the Chalk of Southern England, Proceeding of the Geologist's Association, 108, 293-315, 1997.

Busby, J. P., Senfaute, G., Gourry, J. C., Lawrence, J. A., Pederson, S. A. S., and Mortimore, R. N.: Developing tools for the prediction of catastrophic coastal cliff collapse, in: Proceedings of the 7th International Symposium - Delivering Sustainable Coasts: Connecting Science and Policy, Aberdeen, Scotland, UK, 2004, 596-601, 2004.

Busby, J. and Jackson, P.: The application of time-lapse azimuthal apparent resistivity measurements for the prediction of coastal cliff failure, J. Appl. Geophys., 59, 261-272, 2006.

Collins, B. D. and Sitar, N.: Processes of coastal bluff erosion in weakly lithified sands, Pacifica, California, USA, Geomorphology, 97, 483-501, 2008.

Costa, S.: Le recul des falaises du pays de Caux, Bull. Inf. Géol. Bass. Paris, 37, 31-34, 2000.

Costa, S., Delahaye, D., Freiré-Diaz, S., Di Nocera, L., Davidson, R., and Plessis E.: Quantification of Normandy and Picardy chalk cliff retreat by photogrammetric analysis, edited by: Mortimore, R. N. and Duperret, A., Coastal chalk Cliff Instability, Geological Society, London, Engineering Geology Special Publications, 20, 139-148, 2004.

Deparis, J.: Etude des éboulements rocheux par méthodes géophysiques, $\mathrm{Ph} . \mathrm{D}$. thesis, Laboratoire de géophysique interne et de tectonophysique, Université Joseph Fourier - Grenoble I, Grenoble, 245 pp., 2007. 
Deparis, J., Garambois, S., and Hantz, D.: On the potential of ground penetrating radar to help rock fall hazard assessment: A case study of a limestone slab, gorges de la bourne (French Alps), Eng. Geol., 94, 89-102, 2007.

Dewez, T. J. B., Rohmer, J., and Closset, L.: Laser survey and mechanical modelling of chalky sea cliff collapse in Normandy, France, in: Proceedings of the International Conference on Landslides and Climate Change, Ventnor, England, 2007, 281288, 2007.

Dornbusch, U., Robinson, D. A., Moses, C., Rendel, W., and Costa, S.: Retreat of chalk cliffs in the eastern English Channel during the last century, Journal of Maps, 71-78, 2006.

Driad-Lebeau, L., Lahaie, F., Al Heib, A., Josien, J. P., Bigarre, P., and Noirel, J. F.: Seismic and geotechnical investigations following a rockburst in a complex french mining district, Int. J. Coal Geol., 64, 66-78, 2005.

Duperret, A., Genter, A., Martinez, A., Mortimore, R. N., Delacourt, B., and Pomerai, M. R.: Coastal Rock Cliff Erosion by Collapse at Puys, France: The Role of Impervious Seams within Chalk of NW Europe, J. Coastal Res., 18(1), 52-61, 2002.

Duperret, A., Genter, A., Martinez, A., and Mortimore, R. N.: Coastal chalk cliff instability in NW France: the role of lithology, fracture pattern and rainfall, edited by: Mortimore, R. N. and Duperret A., in: Coastal chalk Cliff Instability, Geological Society, London, Eng. Geol. Sp., 20, 33-55, 2004.

Dussauge-Peisser, C., Helmstetter, A., Grasso, J.-R., Hantz, D., Desvarreux, P., Jeannin, M., and Giraud, A.: Probabilistic approach to rock fall hazard assessment: potential of historical data analysis, Nat. Hazards Earth Syst. Sci., 2, 15-26, 2002,

http://www.nat-hazards-earth-syst-sci.net/2/15/2002/.

European Final Report: Prediction of the erosion of cliffed terrains - PROTECT, Open File Rep. evk3-ct-2000-00029, 110 pp., 2004.

Frayssines, M. and Hantz, D.: Failure mechanisms and triggering factors in calcareous cliffs of the subalpine ranges (French Alps), Eng. Geol., 86, 256-270, 2006.

Frayssines M.: Contribution à l'évaluation de l'aléa éboulement rocheux (rupture), ph.D thèse, Laboratoire Interdisciplinaire de Recherche Impliquant la Géologie et la Mécanique, Université Joseph Fourier - Grenoble I, Grenoble, 218 pp., 2005.

Genter, A., Duperret, A., Martinez, A., Mortimore, R. N., and Vila, J.-L.: Multiscale fracture analysis along the French chalk coastline for investigating erosion by cliff collapse, edited by: Mortimore, R. N. and Duperret, A., in: Coastal chalk Cliff Instability, Geological Society, London, Eng. Geol. Sp., 20, 57-74, 2004.

Got, J. L., Frechet, J., and Klein, F. W.: Deep fault plane geometry inferred from multiplet relative relocation beneath the south flank of Kilauea, J. Geophys. Res.-Sol. Ea., 99, 15375-15386, 1994.

Gunzburger, Y., Merrien-Soukatchoff, V., and Guglielmi, Y.: Influence of daily surface temperature fluctuations on rock slope stability: Case study of the rochers de Valabres slope (France), Int. J. Rock Mech. Min., 42, 331-349, 2005.

Hantz, D., Vengeon, J. M., and Dussauge-Peisser, C.: An historical, geomechanical and probabilistic approach to rock-fall hazard assessment, Nat. Hazards Earth Syst. Sci., 3, 693-701, 2003, http://www.nat-hazards-earth-syst-sci.net/3/693/2003/.

Hoek, E. and Bray, J.: Rock slope engineering Revised third edition ed., Institution of Mining and Metallurgy, London, 358 pp., 1981. Hungr, O., Evans, S. G., and Harzard, J.: Magnitude and frequency of rock falls and rock slides along the main transportation corridors of southwestern British Columbia, Can. Geotech. J., 36, 224-238, 1999.

Iannacchione, A., Esterhuizen, G., Bajpayee, T., Swanson, P., and Chapman, M.: Characteristics of mining-iinduced seismicity associated with roof falls and roof caving events, in: Proceedings of the 40th US Rock Mechanics Symposium - Rock Mechanics for Energy, Mineral and Infrastructure Development in the Northern Regions Anchorage, AK, 1-10, 2005.

Jaboyedoff, M., Ornstein, P., and Rouiller, J.-D.: Design of a geodetic database and associated tools for monitoring rock-slope movements: the example of the top of Randa rockfall scar, Nat. Hazards Earth Syst. Sci., 4, 187-196, 2004, http://www.nat-hazards-earth-syst-sci.net/4/187/2004/.

Jeannin, M., Garambois, S., Gregoire, C., and Jongmans, D.: Multiconfiguration gpr measurements for geometric fracture characterization in limestone cliffs (Alps), Geophysics, 71, B85-B92, 2006.

Jeannin, M.: Etude des processus d'instabilités des versants rocheux par prospection géophysique. Apport du radar géologique, $\mathrm{PhD}$ thèse, Laboratoire de géophysique interne et tectonophysique, Université Joseph Fourier - Grenoble I, Grenoble, 241 pp., 2005.

Kanamori, H., Given, J. W., and Lay, T.: Analysis of seismic body waves excited by the mount St-Helens eruption of May 18, 1980, J. Geophys. Res., 89, 1856-1866, 1984.

Kranz, R. L.: Crack growth and development during creep of Barre granite, Int. J. Rock Mech. Min., 16, 23-35, 1979.

Lamont-Black, J. and Mortimore, R.: Dissolution tubules: A new karst structure from the English chalk, Zeitschrift für Geomorphologie, 44, 469-489, 2000.

Lockner, D.: The role of acoustic-emission in the study of rock fracture, Int. J. Rock Mech. Min., 30, 883-899, 1993.

Marques, F. M. S. F.: Rates, patterns and timing of cliff retreat, A case study on the west coast of Portugal, Zeitschrift für Geomorphologie-Supplementbande, 144, 231-257, 2006.

Merrien-Soukatchoff, V., Clement, C., Gunzburger, Y., and Dunner, C.: Thermal effects on rock slopes : Case study of the "Rochers de Valabres" Slope (France), Proceedings of the 11th Congress of the international society for rock mechanics, Lisbon, Portugal, 2007.

Mikos, M., Vidmar, A., and Brilly, M.: Using a laser measurement system for monitoring morphological changes on the Strug rock fall, Slovenia, Nat. Hazards Earth Syst. Sci., 5, 143-153, 2005, http://www.nat-hazards-earth-syst-sci.net/5/143/2005/.

Milev, A. M., Spottiswoode, S. M., and Noble, K. R.: Mine-induced seismicity at east-rand proprietary mines, Int. J. Rock Mech. Min., 32, 629-632, 1995.

Moore, J. R., Sander, J. W., Cuffey, K. M., Haught, J. R., and Glaser, S. D.: Seismic monitoring of rock fall, helmet mountain, British Columbia, in: Proceedings of the First Canada - US Rock Mechanics Symposium. Rock Mechanics: Meeting society's challenges and demands, Vancouver, Canada, 2007, 895-900, 2007.

Mortimore, R. N. and Pomerol, B.: Correlation of the upper cretaceous white chalk (Turonian to Campanian) in the Anglo-Paris Basin, Proceedings of the Geologist's Association, 98, 97-143, 1987.

Mortimore, R. N., Wood, C. J., and Gallois, R. W.: British upper Cretaceous Stratigraphy, Geological conservation review, se- 
ries 23, 2001.

Mortimore, R. N., Lawrence, J., Pope, D., Duperret, A., and Genter, A.: Coastal cliff geohazards in weak rock: The UK chalk cliffs of Sussex, edited by: Mortimore, R. N. and Duperret, A., in: Coastal chalk cliff instability, Geological Society, London, Eng. Geol. Sp., 20, 3-31, 2004.

Moriya, H., Nagano, K., and Niitsuma, H.: Precise source location of $\mathrm{AE}$ doublets by spectral matrix analysis of tri-axial hodogram, Geophysics, 59, 36-45, 1994.

Nishizawa, O., Kusunose, K., and Onai, K.: A study of space-time distribution of ae hypocenters in a rock sample under uniaxial compression, Bull. Geol. Surv. Japan, 32, 473-486, 1981.

Nishizawa, O., Onai, K., and Kusunose, K.: Hypocenter distribution and focal mechanism of events during 2-stress stage creep in Yugawara andesite, Pure Appl. Geophys., 122, 36-52, 1984.

Ohnaka, M. and Mogi, K.: Frequency dependence of acoustic emission activity in rocks under incremental uniaxial compression, B. Earthq. Res. I., 56, 67-89, 1981.

Ohnaka, M. and Mogi, K.: Frequency characteristics of acoustic emission in rocks under uniaxial compression and its relation to the fracturing process to failure, J. Geophys. Res., 87, 38733884, 1982.

Poupinet, G., Fréchet, J., Ellsworth, W. L., Frémont, M. J., and Glangeaud, F.: Doublet analysis; improved accuracy for earthquake prediction study, EPR, Earthquake. Pred. Res., 1, 147159, 1985.

Priest, S. D.: Discontinuity analysis for rock engineering, Chapman and Hall, London, 473 pp., 1993.

Roch, K. H., Chwatal, W., and Bruckl, E.: Potentials of monitoring rock fall hazards by GPR: Considering as example the results of Salzburg, Landslides, 3, 87-94, 2006.

Senfaute, G., Chambon, C., Bigarre, P., Guise, Y., and Josien, J. P.: Spatial distribution of mining tremors and the relationship to rockburst hazard, Pure Appl. Geophys., 150, 3-4, 1997.

Senfaute, G., Abdul Wahed, M., Lenhard, F., and Morel, J.: Technique d'écoute microsismique appliquée au risque d'effondrement dans les mines du bassin ferrifère lorrain, Revue Française de Géotechnique, 92, 57-62, 2000.
Senfaute, G., Merrien-Soukatchoff, V., Morel, J., and Gourry, J. C.: Microseismic monitoring applied to prediction of chalk cliffs collapses and contribution of numerical modelling, in: Proceedings of the International Conference on Fast slope movementsprediction and prevention for risk mitigation, Naples, Italy, 2003, 463-468, 2003.

Senfaute, G., Amitrano, D., Lenhard, F., and Morel, J.: Etude expérimentale en laboratoire de l'endommagement des roches de craie par méthodes acoustiques et corrélation avec des résultats in situ, Revue Française de Géotechnique, 110, 9-18, 2005.

Senfaute, G., Wassermann, J., and Homand, F.: Induced microseismicity and mechanical response during the experimental flooding of an iron ore mine, in: Proceedings of the Symposium Post-mining 2008, Nancy, 6-8 February, 2008.

Spillmann, T., Maurer, H., Green, A. G., Heincke, B., Willenberg, H., and Husen, S.: Microseismic investigation of an unstable mountain slope in the Swiss Alps, J. Geophys. Res.-Sol. Ea., 112(25), B07301, doi:10.1029/2006JB004723, 2007.

Tapponnier, P. and Brace, W. F.: Development of stress-induced microcracks in westerly granite, Int. J. Rock Mech. Min., 13, 103-112, 1976.

Teixeira, S. B.: Slope mass movements on rocky sea-cliffs: A power-law distributed natural hazard on the Barlavento coast, Algarve, Portugal, Cont. Shelf Res., 26, 1077-1091, 2006.

Vandycke, S. and Bergerat, F.: Brittle tectonic structures and palaeostress analysis in the Isle of Wight, Wessex basin, southern UK, J. Struct. Geol., 23, 393-406, 2001.

Wasserman, J., Senfaute, G., Amitrano, A., and Homand, F.: Evidence of dilatant and non-dilatant damage processes in oolitic iron ore: P-wave velocity and acoustic emission analyses, J. Geophys. Res., doi:10.1111/j.1365-246X.2008.04017.x, 2008.

Wieczorek, G. F., Snyder, J. B., Alger, C. S., and Isaacson, K. A.: Yosemite historical rock fall inventory, US Geol. Surv. Open File Report, 38, 92-387, 1992. 